\title{
Mutant Endoglin in Hereditary Hemorrhagic Telangiectasia Type 1 Is Transiently Expressed Intracellularly and Is Not a Dominant Negative
}

\author{
Nadia Pece, ${ }^{\star}$ Sonia Vera, ${ }^{\star}$ Urszula Cymerman, ${ }^{*}$ Robert I. White, Jr., ${ }^{\ddagger}$ Jeffrey L. Wrana, ${ }^{\S}$ and Michelle Letarte ${ }^{\star}$ \\ *Division of Immunology and Cancer Research, The Hospital for Sick Children and Department of Immunology, University of Toronto, \\ Toronto M5G 1 X8, Canada; ${ }^{\ddagger}$ Department of Diagnostic Radiology, Yale University School of Medicine, New Haven, Connecticut 06520; \\ ${ }^{\S}$ Program in Developmental Biology, Division of Gastroenterology, The Hospital for Sick Children, and Department of Medical Genetics \\ and Microbiology, University of Toronto, Toronto M5G 1 X8, Canada
}

\begin{abstract}
Endoglin (CD105), a component of the TGF- $\beta 1$ receptor complex, is the target gene for the dominantly inherited vascular disorder hereditary hemorrhagic telangiectasia type 1 (HHT1). We have identified a novel endoglin splice site mutation, leading to an in-frame deletion of exon 3, in a newborn from a family with HHT. Expression of normal and mutant endoglin proteins was analyzed in umbilical vein endothelial cells from this baby and in activated monocytes from the affected father. In both samples, only normal dimeric endoglin (160 kD) was observed at the cell surface, at $50 \%$ of control levels. Despite an intact transmembrane region, mutant protein was only detectable by metabolic labeling, as an intracellular homodimer of $130 \mathrm{kD}$. In monocytes from three clinically affected HHT1 patients, with known mutations creating premature stop codons in exons 8 and 10, surface endoglin was also reduced by half and no mutant was detected. Overexpression into COS-1 cells of endoglin cDNA truncated in exons 7 and 11, revealed their intracellular expression, inability to be secreted and to form heterodimers at the cell surface. These results indicate that mutated forms of endoglin are transiently expressed intracellularly and not likely to act as dominant negative proteins, as proposed previously. A reduction in the level of functional endoglin is thus involved in the generation of HHT1, and associated arteriovenous malformations. (J. Clin. Invest. 1997. 100:2568-2579.) Key words: hereditary diseases • vascular endothelium • arteriovenous malformations • transforming growth factor beta receptors $\bullet$ monocytes
\end{abstract}

\section{Introduction}

Hereditary hemorrhagic telangiectasia (HHT, ${ }^{1}$ also known as Rendu-Osler-Weber Syndrome) is an autosomal dominant vascular disorder which affects $\sim 1: 10,000$ individuals and shows an age-related penetrance $(1,2)$. The most commonly

Address correspondence to Michelle Letarte, Division of Immunology and Cancer Research, The Hospital for Sick Children, 555 University Ave., Toronto M5G 1X8, Canada. Phone: 416-813-6258; FAX: 416-813-6255; E-mail: mablab@sickkids.on.ca

Received for publication 23 April 1997 and accepted in revised form 15 September 1997.

J. Clin. Invest.

(C) The American Society for Clinical Investigation, Inc. 0021-9738/97/11/2568/12 \$2.00

Volume 100, Number 10, November 1997, 2568-2579

http://www.jci.org affected sites include the nasal, mucocutaneous, gastrointestinal, pulmonary, cerebral, and hepatic vascular beds. Most patients have frequent nose bleeds by age 21 and skin telangiectases by age 40 , and a significant percentage of patients develop gastrointestinal bleeding during the sixth and seventh decade $(1,2)$. Telangiectases arise from the dilatation of postcapillary venules that eventually connect directly with the arterioles bypassing the capillary bed (3). Arteriovenous malformations are much larger lesions associated with the dilatation of both feeding arteries and draining veins; vessels are highly convoluted and veins become arterialized in an attempt to sustain the increase in blood pressure associated with the shunt (1). Pulmonary arteriovenous malformations (PAVM), estimated to be present in 15-20\% of the overall HHT population, are associated with serious complications such as pulmonary hemorrhage, hypoxia, brain abscess, and stroke. The mean age at time of PAVM diagnosis is about 40 with a range of 1-78 $\mathrm{yr}$ (4). PAVM are more frequent in women and are prone to hemorrhage during pregnancy (5). Cerebral arteriovenous malformations (CAVM) and aneurysms are observed in 10 $20 \%$ of patients and often in those with existing PAVM. They have also been reported in newborns and young children $(6,7)$.

The diagnosis of HHT is often difficult because it masquerades as other diseases as illustrated by a recent case report (8). It is also a heterogeneous disease with respect to the age of onset and the clinical manifestations observed both between families and among members of a single family. In part, this is due to molecular heterogeneity that was first realized by genetic linkage studies; some families clearly mapped to chromosome 9q33-34 while others did not $(9,10)$. Endoglin (CD105), which was assigned to this region previously (11), was defined as the mutated gene, and is referred to as HHT1 (12). A second locus (HHT2) mapping to chromosome 12q was discovered and shown to be the activin receptor-like kinase 1 (ALK1) (13-15). It is postulated that at least one more locus is involved in HHT that is more predominantly associated with liver AVM (16). Analysis of a limited number of families has suggested that symptomatic PAVM (and potentially CAVM) are much more frequent in HHT1 than in HHT2 families (17-19) suggesting that endoglin might be critical to the development and/or maintenance of lung and brain vasculature.

1. Abbreviations used in this paper: ALK1, activin receptor-like kinase 1; CAVM, cerebral arteriovenous malformations; DSS, disuccinimidyl suberate; END, full-length endoglin in the mammalian expression construct pcEXV-1; HHT, hereditary hemorrhagic telangiectasia; HHT1, HHT type 1 ; HUVEC, human umbilical vein endothelial cells; met, methionine; PAVM, pulmonary arteriovenous malformations; T $\beta$ R-I, TGF- $\beta$ type I receptor; T $\beta$ R-II, TGF- $\beta$ type II receptor. 
Endoglin is a homodimeric integral membrane glycoprotein expressed at high levels on vascular endothelial cells (20). Other sites of expression include activated monocytes, where it is observed at lower levels (21). It is a component of the TGF- $\beta 1$ receptor complex in these cells, as it associates with the TGF- $\beta$ type II receptor (T $\beta$ R-II) and the type I receptor (T $\beta R-I$, or ALK5) (22-24). TGF- $\beta$ is implicated in blood vessel formation particularly by regulating extracellular matrix production and endothelial cell interactions with adjacent smooth muscle cells $(25,26)$. TGF- $\beta$ and other members of its superfamily signal through a minimum heteromeric complex of two related transmembrane ser/thr kinase receptors, type I and type II receptors $(27,28)$. For TGF- $\beta$, receptor activation occurs upon binding of ligand to T $\beta$ R-II which recruits and phosphorylates T $\beta$ R-I (ALK5), and then propagates the signal to downstream targets $(27,28)$. The specificity of cellular responses to ligands of the TGF- $\beta$ superfamily is thought to be mediated by the type I receptors $(29,30)$. The recent identification of the Mad-related protein, Smad2 and not the related Smad4, as a substrate for T $\beta R$-I, and a downstream signal effector in the TGF- $\beta$ pathway, supports this model (31, 32). Overexpression of endoglin in the U937 monocytic line led to modulation of several responses to TGF- $\beta 1$ (24), suggesting it acts as a coreceptor for this ligand. The precise biochemical interactions of endoglin within the receptor complex are still poorly understood.

ALK1 is a type I receptor that shares homology with other type I receptors for the TGF- $\beta$ superfamily of ligands. Although ALK1 can associate with TGF- $\beta$ or activin type II receptors when overexpressed in COS-1 cells, in the presence of the appropriate ligand $(33,34)$, its downstream effectors and cellular response(s) have yet to be characterized. Thus, it is unclear whether ALK-1 functions in vivo as a receptor for TGF $\beta$, activin or another ligand of the TGF- $\beta$ superfamily. The findings that endoglin and ALK-1 are target genes for HHT suggest that both proteins are involved in a common pathway controlling vasculogenesis and/or angiogenesis.

10 distinct mutations in the endoglin gene have been re- ported so far, 8 of which give rise to premature stop codons $(12,35,36)$. As these mutations clustered in exons $5-11$, it was suggested that mutant proteins expressed at the cell surface as heterodimers, or secreted locally, could exert dominant negative effects on TGF- $\beta$ responses and contribute to the pathology of HHT1 (35). We now report a novel mutation in endoglin, an exon 3 skip, which leads to the expression of a mutant protein missing 47 amino acids but with an intact transmembrane region. This mutant protein is particularly suited for testing the dominant negative model as it is more likely to be expressed at the cell surface than truncated ones. However, it was only detectable by metabolic labeling, did not form heterodimers with normal endoglin, and did not reach the cell surface. In activated monocytes from three patients with known truncations, no mutant protein could be detected. However, when cDNA corresponding to two other HHT1 endoglin truncations were overexpressed in COS-1 cells, mutant proteins could be detected intracellularly, were not secreted and did not form heterodimers with wild-type endoglin. Thus, mutant endoglin in HHT1 patients appears to be only transiently expressed and is not a dominant negative. Our data strongly suggest that a reduced level of functional endoglin leads to the abnormalities seen in HHT1 patients.

\section{Methods}

Clinical evaluation. Informed consent was obtained from all individuals participating in the study, including clinically diagnosed HHT patients or their spouses, in the case of umbilical cord samples. A positive diagnosis requires any two of the following criteria: recurrent epistaxis, telangiectases elsewhere than in the nasal mucosa, evidence of autosomal inheritance, and visceral involvement $(1,4)$. All patients and families are given a number and clinically diagnosed patients or babies born to HHT families are referred to with the prefix $\mathrm{H}$ (for HHT). Patients H65, H74, and H119 were characterized as cases 1275,1160 , and 1247 in a previous study (35); their mutations lead to premature stops at codons 350,371 , and 472 , respectively, as shown in Fig. 1.

Cell culture. All materials were from GIBCO BRL, Canadian

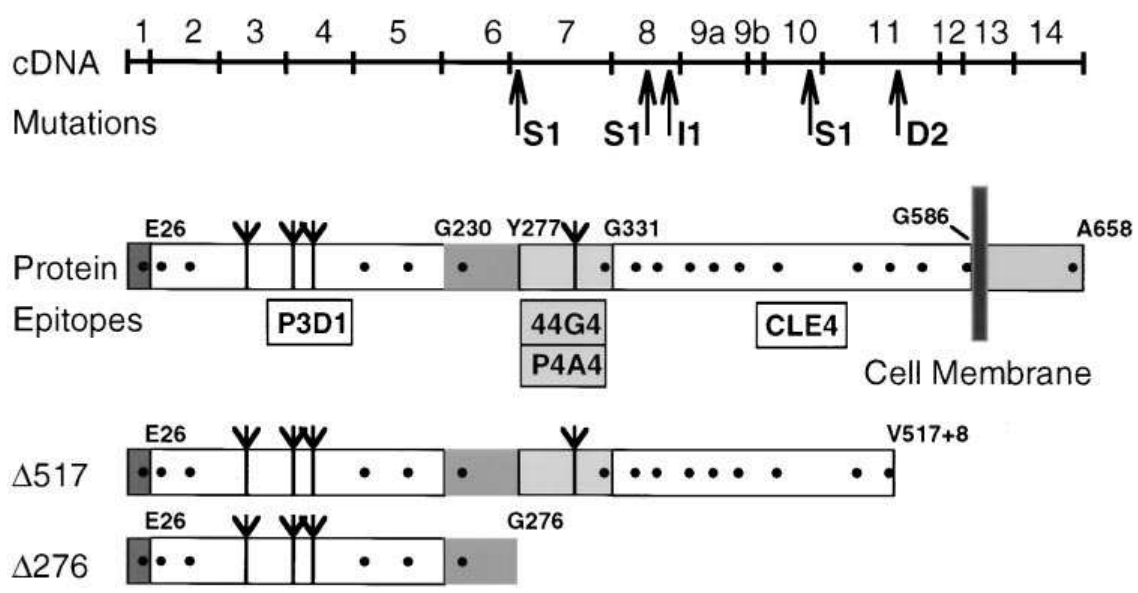
The polypeptide structure of endoglin is also illustrated with the approximate positions of cysteine residues $(\bullet)$ and the potential $\mathrm{NH}_{2}-$ linked glycosylation sites (tridents). The $\mathrm{NH}_{2}$-terminal residue of the mature protein is $\mathrm{E} 26 . \mathrm{mAb}$ recognizing epitopes located in three distinct areas of the extracellular domain of endoglin are depicted: P3D1 binding to the $\mathrm{NH}_{2}$-terminal region (E26-G230), P4A4 and 44G4 binding to the Y277-G331 region, and CLE4 binding to the G331-G586 region. The $\Delta 517$ and $\Delta 276$ truncated forms of endoglin that were engineered, subcloned into the pcEXV vector, and transfected into COS-1 cells are illustrated.

Figure 1. Schematic diagram of endoglin cDNA and protein. The intron/exon boundaries (12) are indicated on the cDNA sequence, the initiation codon ATG corresponding to bp 1 and to $\mathrm{M} 1$ of the leader peptide. The approximate positions of mutations previously linked with HHT1, and relevant to this study, are depicted. A 1-bp substitution (S1; C to $\mathrm{G}$ ) in exon 7 at position 831 creates a stop at codon $276(\Delta 276)$; S1 ( $\mathrm{T}$ to $\mathrm{G}$ ) at position 1050 in exon 8 creates a stop at codon $350(\Delta 350)$; a 1-bp insertion (I1) at position 1111 in exon 8 causes a frameshift that leads to a premature stop at codon $371(\Delta 371)$; S1 (C to T) at position 1414 in exon 10 creates a stop at codon $472(\Delta 472)$; a 2-bp deletion (D2) at position 1553 in exon 11 creates a frameshift that causes a premature stop at codon $517(\Delta 517)(12,35)$.

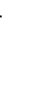


Life Technologies Inc. (Burlington, Ontario, Canada) unless otherwise specified. Endothelial cells were derived from human umbilical veins (HUVEC) from newborns of HHT families and control babies by previously published procedures (37). HUVEC were maintained in Medium 199, containing 10\% FBS (Cansera International Inc., Rexdale, Ontario, Canada), $15 \mathrm{mM}$ Hepes, $2 \mathrm{mM}$ L-glutamine, $30 \mu \mathrm{g} / \mathrm{ml}$ endothelial mitogen (Biomedical Technologies, Inc., Stoughton, MA), $10 \mathrm{U} / \mathrm{ml}$ heparin (Organon Teknika, Toronto, Ontario, Canada), 100 $\mathrm{U} / \mathrm{ml}$ penicillin, $100 \mu \mathrm{g} / \mathrm{ml}$ streptomycin and $0.5 \mu \mathrm{g} / \mathrm{ml}$ amphotercin $\mathrm{B}$, at $37^{\circ} \mathrm{C}$ under $5 \% \mathrm{CO}_{2}, 100 \%$ humidity, and cultured as described (37). For assays, equivalent cell densities and passage numbers were employed with patient and matched controls. As endoglin is downregulated at confluence (38) we always used proliferating HUVEC at subconfluence. Liquid nitrogen stocks of all HUVEC were prepared at passage two. Cells were generally used between passages two and seven.

Mononuclear cells were obtained from acid-citrate-dextrantreated whole venous blood of clinically affected HHT patients and control volunteers by modifications of published procedures (21). Peripheral blood samples were depleted of erythrocytes by $1 \mathrm{~g}$ sedimentation through $4.5 \%$ dextran T-500/0.9\% NaCl (Sigma-Aldrich Canada, Ltd., Mississauga, Ontario, Canada), and mononuclear cells recovered by Ficoll-Paque density gradient centrifugation (Pharmacia Biotech Canada Inc., Quebec, Canada). The mononuclear cells derived from $30 \mathrm{ml}$ of blood were washed in PBS and resuspended in RPMI 1640 containing $10 \%$ heat-inactivated FBS, 2 mM L-glutamine, 100 $\mathrm{U} / \mathrm{ml}$ penicillin, $100 \mu \mathrm{g} / \mathrm{ml}$ streptomycin, and $0.5 \mu \mathrm{g} / \mathrm{ml}$ amphotercin $\mathrm{B}$ and incubated at $37^{\circ} \mathrm{C}$ on a $100-\mathrm{mm}$ plastic tissue culture treated dish for at least $1 \mathrm{~h}$. Nonadherent lymphocytes were removed by washing with prewarmed RPMI 1640 medium without FBS or antibiotics, and monocytes were incubated for at least $16 \mathrm{~h}$ in RPMI 1640 plus FBS and antibiotics at $37^{\circ} \mathrm{C}$ under $5 \% \mathrm{CO}_{2}, 100 \%$ humidity.

Mutation identification. RNA was prepared from HUVEC using TRIZOL $^{\circledR}$ reagent and genomic DNA was isolated using DNAZOL ${ }^{\circledR}$ reagent (GIBCO BRL). cDNA was prepared by reverse transcription in a 50- $\mu \mathrm{l}$ volume containing $1 \mu \mathrm{g}$ oligo dT, $5 \mu \mathrm{g}$ of total RNA as reported previously (39). Oligonucleotide primers E (5'-TGTCTCACTTCATGCCTCCAGCT-3'; bp 966-988) and F (5'-AGGCTGTCCATGTTGAGGCAGT-3'; bp 1322-1343) that span exons 7-10 of endoglin cDNA and N (5'GTCCATTGTGACCTTCAGCCTGTG-3'; bp 82-105) and R (5'-GATGGCAGCTCTGTGGTGTT-3'; bp 100-119) spanning exons 2-4 were used for PCR amplification of cDNA. The sequence of primers required for amplification of exon 3 and flanking intronic sequences were kindly provided by Dr. C. Shovlin (Department of Medicine, University of Edinburgh, Edinburgh, Scotland): forward primer $5^{\prime}$-AACCTATACAAATCTGACT-3' and reverse primer 5'-TGACAGTAGGACTTCCCAT-3'. $1 \mu \mathrm{g}$ of cDNA or genomic template was amplified in a $75-\mu l$ vol containing Perkin-Elmer reagents (Roche Molecular Systems, Branchburg, NJ) in PCR reaction buffer, $1.5 \mathrm{mM} \mathrm{MgCl} 2$, and $200 \mathrm{nM}$ of each dNTP, 150-450 ng of primers using a RoboCycler ${ }^{\circledR}$ (Stratagene Inc., La Jolla, CA). For cDNA using primers $\mathrm{N}$ and $\mathrm{R}$, cycling conditions were: initial denaturation of $2 \mathrm{~min}$ at $94^{\circ} \mathrm{C}, 35$ cycles of $75 \mathrm{~s}$ at $94^{\circ} \mathrm{C}$, $75 \mathrm{~s}$ at $57^{\circ} \mathrm{C}, 90 \mathrm{~s}$ at $72^{\circ} \mathrm{C}$, a final extension of $5 \mathrm{~min}$ at $72^{\circ} \mathrm{C}$. For genomic DNA, cycling conditions were: initial denaturation of $2 \mathrm{~min}$ at $94^{\circ} \mathrm{C}, 35$ cycles $20 \mathrm{~s}$ at $94^{\circ} \mathrm{C}, 30 \mathrm{~s}$ at $51^{\circ} \mathrm{C}, 55 \mathrm{~s}$ at $72^{\circ} \mathrm{C}$, and final extension of $5 \mathrm{~min}$ at $72^{\circ} \mathrm{C}$. PCR products were fractionated by agarose gel electrophoresis, excised and purified by Qiaex ${ }^{\circledR}$ (QIAGEN Inc., Chatsworth, CA). cDNA products equivalent to 100-300 ng were sequenced in both $5^{\prime}$ and $3^{\prime}$ directions using the Amplicycle ${ }^{\circledR}$ sequencing $\left[\alpha{ }^{33} \mathrm{P}\right] \mathrm{dCTP}$ incorporation protocol and kit (Perkin-Elmer, Roche Molecular Systems), and reactions were run on $6 \%$ acrylamide sequencing gels containing urea. Genomic products were sequenced using a cycle sequencing protocol. A reaction mix containing $30 \mathrm{ng}$ of template, $30 \mathrm{ng}$ of CY5.5 forward labeled primer, $4 \mathrm{U}$ of ThermoSequenase $^{\mathrm{TM}}$ enzyme (Amersham Life Sciences, Oakville, Ontario, Canada) in ThermoSequenase ${ }^{\mathrm{TM}}$ buffer was prepared and added to each of d/dd NTP terminators at a ratio of $750 \mu \mathrm{M}: 7.5 \mu \mathrm{M}$. Cycle se- quencing conditions were: initial denaturation of $2 \mathrm{~min}$ at $94^{\circ} \mathrm{C} ; 33 \mathrm{cy}-$ cles of $50 \mathrm{~s}$ at $94^{\circ} \mathrm{C}, 30 \mathrm{~s}$ at $50^{\circ} \mathrm{C}, 1 \mathrm{~min}$ at $70^{\circ} \mathrm{C}$, and a final extension of $2 \mathrm{~min}$ at $72^{\circ} \mathrm{C}$. Products were resolved on a Microgeneblaster ${ }^{\circledR}$ automated sequencing apparatus from Visible Genetics Inc. (VGI; Toronto, Ontario, Canada).

Preparation of expression constructs and transfection. Full-length endoglin in the mammalian expression construct pcEXV-1 (END) was provided by Dr. C. Bernabeu (Centro de Investigaciones Biológicas, CSIC, Madrid, Spain) (40). Constructs $\Delta 276$ and $\Delta 517$ representing HHT1 mutations with stops at codons 276 and 517 (reference 12; see Fig. 1) were prepared by long PCR by Dr. S. Pichuantes (Chiron Corporation, Emeryville, CA). Primers were designed to recreate the amino terminus with the translational start preceded by a HindIII site (forward primer), and two stop codons followed by a BamHI site were engineered at desired positions (reverse primers). Forward primer: 5'-CACGCCAAGCTTATGGACCGCGGCACGCTCCCTCTGGCTGTT-3'. Reverse primer ( $\Delta 276)$ : 5'-TCTTGGATCCTACTA(TTC)TCCAGTGGTCCAGATCTGCATGTTGTG-3'. Reverse primer ( $\Delta 517)$ : 5'-TCTTGGATCCTATCACCTCGGGGCTTGGGGACAGCAGT(CAC)ACA-3'. Translational start and stop codons are in bold, restriction sites are underlined, and position of the last codon in the respective patient cDNA are in brackets. PCR products were subcloned into HindIII and BamHI sites of Puc19. The 5' and 3' ends of the inserts were sequenced before subcloning into pcEXV-1 by blunt ligation into the EcoR1 site.

COS-1 cells were maintained in DME, high glucose, with $10 \%$ FBS, $2 \mathrm{mM}$ L-glutamine, $100 \mathrm{U} / \mathrm{ml}$ penicillin, $100 \mu \mathrm{g} / \mathrm{ml}$ streptomycin, and $0.5 \mu \mathrm{g} / \mathrm{ml}$ amphotercin B. Expression constructs $\Delta 276$ and $\Delta 517$ were each transiently transfected with and without the wild-type endoglin, END construct, using the DEAE-dextran method as described $(30,41)$.

Antibodies. All antibodies to endoglin have been characterized previously. mAb $44 \mathrm{G} 4$ originally defined endoglin $(42,43)$ and was used as the prototype antibody to CD105 in the 5th and 6th International Leukocyte Differentiation Workshops $(44,45)$. CLE4 ascites, was provided by Dr. S. Kumar (University of Manchester, Manchester, United Kingdom) while P3D1 and P4A4 hybridoma were provided by Dr. E.A. Wayner (Fred Hutchinson Cancer Research Center, Seattle, WA). Recently, we demonstrated (46) by CELISA, ELISA, and Western blot assays with bacterially expressed fragments of endoglin that mAb P3D1 reacts with an epitope located between the $\mathrm{NH}_{2}$-terminal residue E26 and $\mathrm{G} 230$, while $\mathrm{P} 4 \mathrm{~A} 4$ and $44 \mathrm{G} 4$ react with region Y277-G331 and CLE-4 reacts with an epitope located between G331 and G586. (Fig. 1). mAb 5.6E to CD31 (PECAM) was purchased from AMAC Inc. (Westbrook, ME), while mAb JBS5 to $\alpha 5 \beta 1$ integrin was a gift from Dr. J.A. Wilkins (University of Manitoba, Winnipeg, Canada). As all mAb used were of IgG1 isotype, a control IgG1 was used (Coulter Electronics, Hialeah, FL). C16 is a polyclonal antisera raised in rabbits by immunization with a synthetic peptide corresponding to amino acids $550-565$ of the highly conserved carboxy-terminal of human type II TGF- $\beta$ receptor (Santa Cruz Biotechnology Inc., Santa Cruz, CA).

Flow cytometry. HUVEC were detached by brief exposure to trypsin-EDTA and washed in $\mathrm{Ca}^{2+}-\mathrm{Mg}^{2+}$-free PBS plus $2 \%$ FBS. Cells $\left(1 \times 10^{6}\right)$ were incubated with saturating amounts of $\mathrm{mAb}$, predetermined for each antibody by titration, and with FITC-conjugated $\mathrm{F}\left(\mathrm{ab}^{\prime}\right)_{2}$ goat anti-mouse IgG (Tago Inc., Burlingame, CA). IgG1 isotype control was included in all experiments and percent positive cells and mean fluorescence intensity were determined relative to that control. Patient samples were run in parallel with control HUVEC and all samples were analyzed on the FACScan ${ }^{\circledR}$ (Becton Dickinson, Mountain View, CA).

Western blot analysis. Equivalent numbers of HUVEC at subconfluence (80-90\%) were solubilized in lysis buffer (0.01 M Tris, $\mathrm{pH}$ 7.5, $0.128 \mathrm{M} \mathrm{NaCl}, 1 \mathrm{mM}$ EDTA, $1 \%$ Triton X-100, and a cocktail of inhibitors) as published previously (47). Varying concentrations of protein estimated with a Bio-Rad protein assay (Bio-Rad Laboratories [Canada] Ltd, Mississauga, Ontario, Canada), were fractionated by SDS-PAGE ( $6 \%$, nonreducing conditions) and transferred elec- 
trophoretically onto nitrocellulose filters for $1 \mathrm{~h}$ at $45 \mathrm{~V}$ using an Xcell II Mini-Cell Trans-Blot apparatus (Novex Experimental Technology, San Diego, CA). Filters were blocked for $1 \mathrm{~h}$ in TBS-T $(0.2 \mathrm{M}$ Tris, $\mathrm{pH} 7.5,0.137 \mathrm{M} \mathrm{NaCl}, 0.1 \%$ Tween 20 ) containing $5 \%$ dry skim milk powder. Endoglin was detected by incubation for $1 \mathrm{~h}$ with CLE4 ascites (750-fold dilution) in TBS-T, followed by 30 min with HRPconjugated rabbit anti-mouse $\mathrm{IgG}$ antibody (H\&L, 5,000-fold dilution; Jackson ImmunoResearch, Biocan, Mississauga, Ontario, Canada) and an enhanced chemiluminescence detection kit (ECL ${ }^{\circledR}$; Amersham Life Sciences) using the protocols provided. Multiple exposures using Hyper-film (Amersham Life Sciences) were obtained.

Metabolic labeling. Equivalent numbers of HUVEC, or transiently transfected COS-1 cells at subconfluence (80-90\%), as well as activated monocytes from $30 \mathrm{ml}$ of blood were labeled for 4-6 h with $100 \mu \mathrm{Ci} / \mathrm{ml}\left[{ }^{35} \mathrm{~S}\right]$ methionine (met) (trans-label; ICN Pharmaceuticals, Montreal, Canada) in met-free DME (low glucose; GIBCO BRL) and solubilized in lysis buffer $(1 \mathrm{ml} / 100 \mathrm{~mm}$ dish $)$ as described for Western blot analysis. Samples and respective matched controls for each cell type were prepared in parallel, divided equally, and immunoprecipitated with saturating amounts of $\mathrm{mAb}$ as indicated $(\mathrm{IgG}, 2$ $\mu \mathrm{g}$; P3D1, $4 \mu \mathrm{g}$; P4A4, $1.6 \mu \mathrm{g}$; CLE4, $8 \mu \mathrm{g}$ ). Immune complexes were collected with BSA adsorbed Gamma-bind ${ }^{\circledR}$ G Sepharose ${ }^{\circledR}$ (Pharmacia Biotech Canada Inc.), and washed once with lysis buffer (without inhibitors), twice each with RIPA (0.05 M Tris- $\mathrm{HCl}, \mathrm{pH} 7.4,0.01 \mathrm{M}$ $\mathrm{NaCl}, 1 \mathrm{mM}$ EDTA, $0.1 \%$ SDS, $0.5 \%$ Triton X-100, $1 \%$ deoxycholate) and TNTE buffer (0.05 M Tris-HCl, $\mathrm{pH} 7.4,0.01 \mathrm{M} \mathrm{NaCl}, 0.1 \%$ Triton X-100, $1 \mathrm{mM}$ EDTA). Samples were eluted by heating at $>95^{\circ} \mathrm{C}$ for $2 \mathrm{~min}$ in nonreducing gel sample buffer $(60 \mathrm{mM}$ Tris$\mathrm{HCl}, \mathrm{pH} 6.8,2 \%$ SDS, $10 \%$ glycerol, $0.05 \%$ bromophenol blue) and reduced where indicated with $50 \mathrm{mM}$ DTT. To quantitate endoglin expression and correct for differences in yield between samples and respective matched controls, aliquots of total lysate were precipitated with $10 \%$ TCA, collected on glass-fiber filters, and total incorporation was determined. Equivalent $\mathrm{cpm}$ were fractionated by SDSPAGE (4-12\% gradient gels, Novex Experimental Technology), gels were fixed, soaked in Amplify ${ }^{\circledR}$ (Amersham Life Sciences), and $\mathrm{X}$-OMAT $\mathrm{AR}^{\circledR}$ films were exposed with dried gels (Eastman Kodak Company, Rochester, NY). Exposure time was usually $8-48 \mathrm{~h}$ for HUVEC and transiently transfected COS-1, and 3-5 d for monocytes. Radioactivity in detectable bands was quantitated using a phosphorimager and Image Quant Software (Molecular Dynamics, Sunnyvale, CA). The patient/control pixel value ratios were calculated for each $\mathrm{mAb}$, under reduced and nonreduced conditions and the mean \pm SD was determined from at least four values. Where conditioned media was analyzed, all of the labeling media from each sample was immunoprecipitated in an identical fashion to the lysates; total eluates of each immunoprecipitate were divided in two and fractionated under reducing and nonreducing conditions.

Cell surface biotinylation. Equivalent numbers of HUVEC, or transiently transfected COS-1 cells at subconfluence (80-90\%) were surface labeled with biotin as reported (48) except $0.3 \mathrm{mg} / \mathrm{ml}$ of sulfosuccinimydyl 6 (biotinamido)-hexanoate (NHS-LC-biotin; Pierce Chemical Co., Rockford, IL) was used. Cells were lysed and immunoprecipitated as described for metabolic labeling except lysates were precleared for at least $1 \mathrm{~h}$ with BSA adsorbed Protein A Sepharose ${ }^{\circledR}$ CL-4B (Pharmacia Biotech Canada Inc.). Total protein was estimated and equal amounts were used for immunoprecipitation. Eluates were fractionated on $4-12 \%$ SDS-PAGE gels, transferred to PVDF nylon membranes and blocked as described for Western blots. Membranes were probed with Streptavidin-HRP (400-fold dilution in TBS-T; Amersham Life Sciences) for $20 \mathrm{~min}$ and biotinylated proteins were detected using ECL (Amersham Life Sciences); multiple exposures were obtained.

Affinity labeling. TGF- $\beta 1$ from R \& D Systems (Minneapolis, $\mathrm{MN})$ was iodinated with $\left[{ }^{125} \mathrm{I}\right]$ using chloramine-T as described previously (49). To visualize TGF- $\beta$ receptors on SDS-PAGE gels, HUVEC monolayers were affinity labeled with $100 \mathrm{pM}\left[{ }^{125}\right.$ I]TGF- $\beta 1$, cross-linked with disuccinimidyl suberate (DSS; Pierce Chemical Co.) and lysed as described $(39,47)$. Aliquots $(300-500 \mu l)$ of total cell lysates containing equivalent protein were subjected to immunoprecipitation with control IgG $(2 \mu \mathrm{g})$, mAb P3D1 $(4 \mu \mathrm{g})$, or polyclonal antibody C16 to T $\beta$ R-II (1 $\mu \mathrm{g} \mathrm{IgG)}$. Immune complexes were collected with Protein A or Protein G Sepharose (Pharmacia Biotech Canada Inc.) as described for metabolic labeling, and washed three times with lysis buffer (without inhibitors). Eluted complexes or total lysates were visualized by separation on SDS-PAGE (4-12\% gradient gels; Novex Experimental Technology), autoradiography, and phosphorimager analysis.

Proliferation assay. HUVEC were seeded at 5,000 cells per well (96-well plate) in complete Medium 199 described above containing $10 \%$ FBS, but only $3 \mu \mathrm{g} / \mathrm{ml}$ ECGF. After cells attached, TGF- $\beta 1$ was added at concentrations of $0-50 \mathrm{pM}$ and incubated for $48 \mathrm{~h}$, including a 6 -h pulse with $\left[{ }^{3} \mathrm{H}\right]$ thymidine $(1 \mu \mathrm{Ci}$ per well). Cells were lysed with water, harvested with a microplate harvester (Inotech Biosystems International, Inc., Lansing, MI), and radioactive incorporation was de-
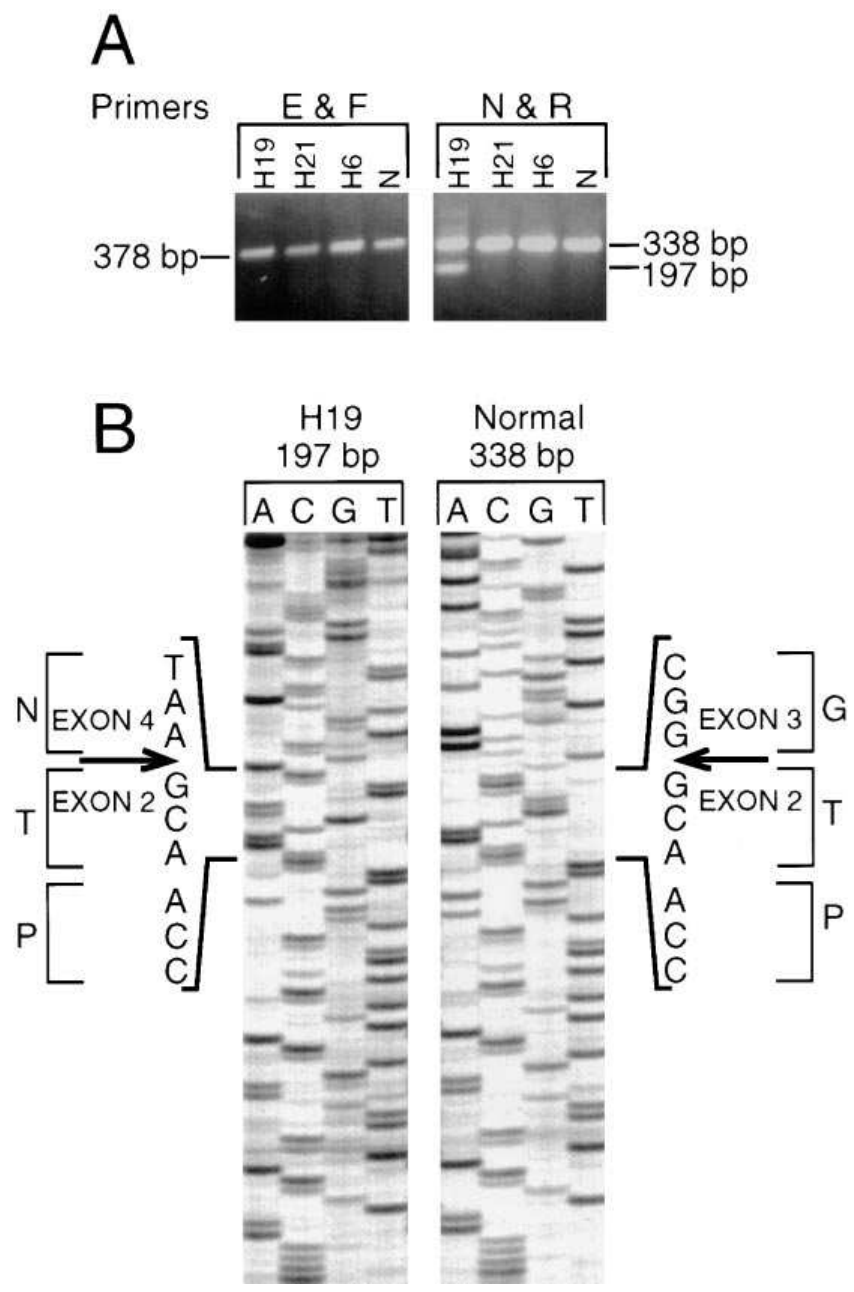

Figure 2. Identification of an in-frame deletion of exon 3 in $\mathrm{H} 19$ HUVEC. $(A)$ cDNA was prepared from H19, and other HUVEC samples including cords from babies from other HHT families (H21 and $H 6)$ as well as normal $(N)$, then amplified by PCR with primers $\mathrm{E}$ and $\mathrm{F}$, spanning exons $7-10$ of cDNA giving the expected product of 378 bp seen in all samples. With primers $\mathrm{N}$ and $\mathrm{R}$, spanning exons 2-4, a product of 197 bp was seen only in the H19 sample in addition to the expected product of 338 bp. (B) Forward sequence of the 197bp PCR product from the H19 sample and of the 338-bp PCR product in the normal sample using primer $\mathrm{N}$ reveals an in-frame deletion of exon 3 in the cDNA of H19. 
termined by liquid scintillation analysis (Beckman Instruments, Inc., Fullerton, CA). These conditions were optimized for cell density, growth factor concentration, time in culture, and length of pulse with multiple preparations of HUVEC to obtain maximum inhibition of proliferation by TGF- $\beta 1$. They are similar to standard conditions reported for different types of cells in response to TGF- $\beta 1$ and related growth factors $(50,51)$.

\section{Results}

Identification of a novel endoglin mutation associated with HHT1. To identify endoglin mutations and to study the expression of putative mutant endoglin proteins, we derived HUVEC from newborn babies from clinically diagnosed HHT families. HUVEC are the best available source of vessels and express high levels of endoglin (20). As HHT is a dominantly inherited and genetically heterogeneous disorder $(9,10,13-15$, 18,52 ), each child has a $50 \%$ chance of carrying a mutated gene and a lesser chance of being of HHT type 1 . When we analyzed HUVEC sample H19 from family 9, by RT-PCR analysis with primers $\mathrm{N}$ and $\mathrm{R}$, which span exons 2 and 4 of endoglin

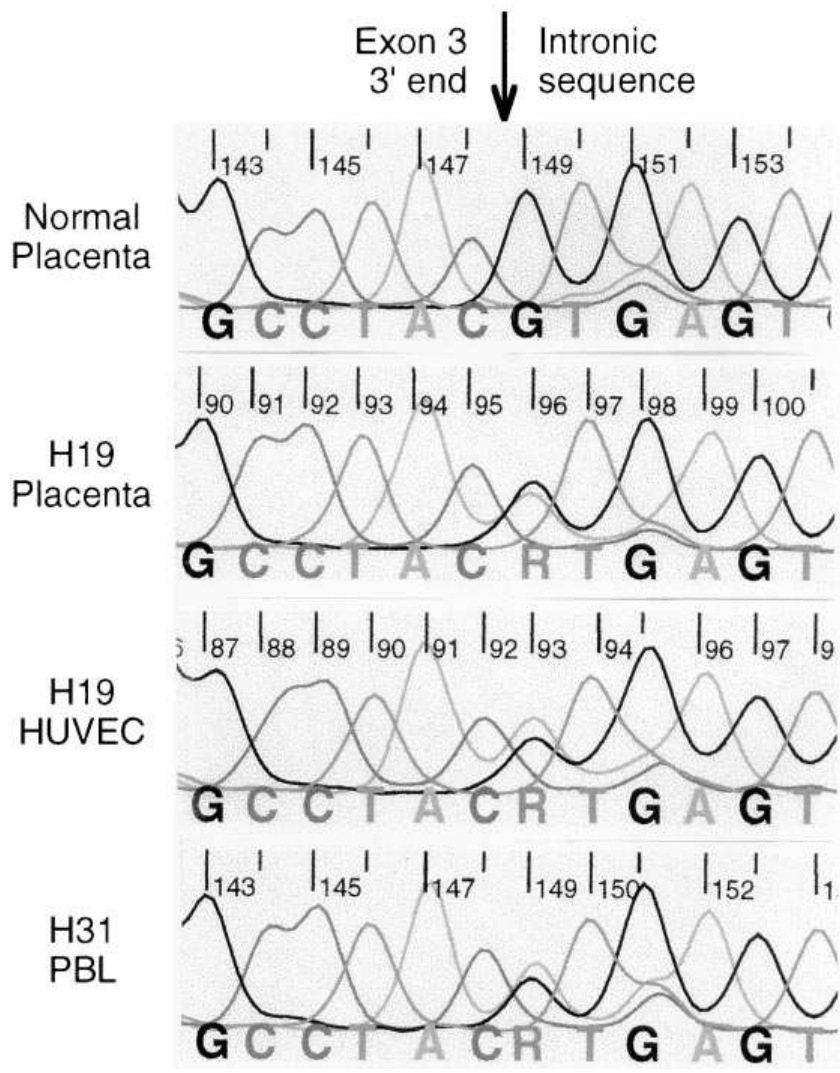

Figure 3. Analysis of genomic DNA from family 9 reveals a splice site mutation that leads to an exon 3 skip. Exon 3 and flanking intronic sequence was amplified by PCR from genomic DNA isolated from normal placenta, H19 placenta, H19 HUVEC, and PBL from $\mathrm{H} 31$, the clinically affected father of H19. Purified products were sequenced using a cycle sequencing protocol and resolved using a Microgeneblaster $^{\circledR}$ automated sequencing apparatus (VGI). The profiles depicting sequence of the $3^{\prime}$-exon $3 /$ intron boundary reveal a mixed sequence ( $\mathrm{R}=\mathrm{G}$ or $\mathrm{A})$ in $\mathrm{H} 19$ and $\mathrm{H} 31$ samples; thus, a $\mathrm{G}$ to A substitution at the invariant intronic/GT splice donor sequence is seen in one copy of the END gene.
A

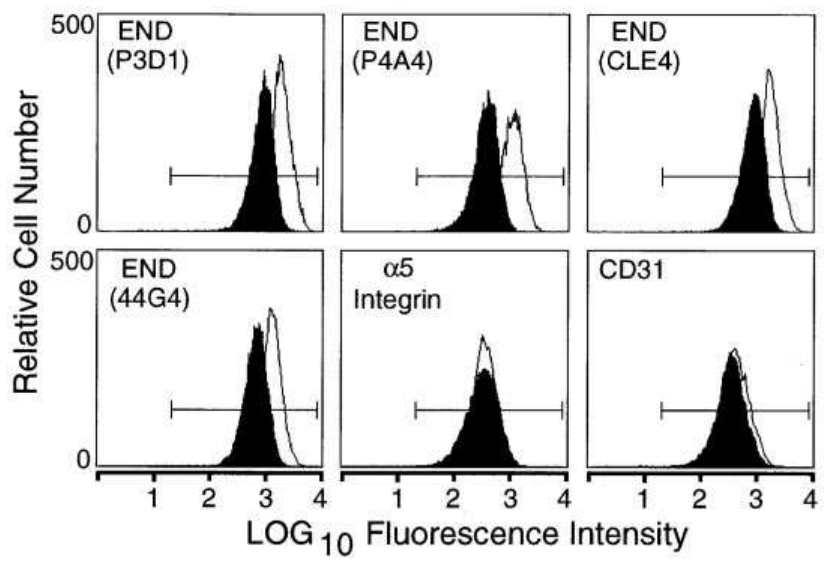

B

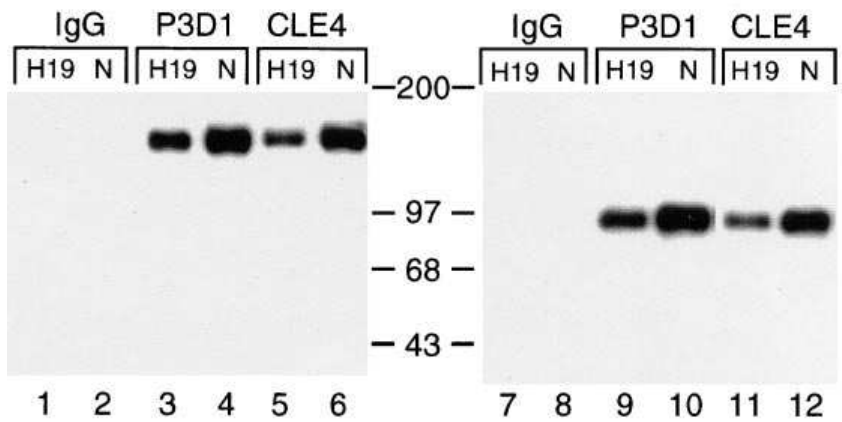

Figure 4. Mutant endoglin from H19 HUVEC is not detected at the cell surface, and normal endoglin is reduced by half. $(A)$ Flow cytometry analysis of endoglin (END) on $\mathrm{H} 19$ (black) versus normal (white) HUVEC was performed as described in Methods. Greater than $98 \%$ of cells are positive with all $\mathrm{mAb}$ relative to the $\mathrm{IgG} 1$ control used to define the gates shown. The mean fluorescence intensity of endoglin on H19 and normal HUVEC are estimated relative to the control from the profiles obtained (note the logarithmic scale) with the $4 \mathrm{mAb}$ tested P3D1, P4A4, CLE4 and 44G4. The expression of $\alpha 5 \beta 1$ integrin and CD31 (PECAM) was also measured. (B) H19 and normal $(N)$ HUVEC were surface labeled with NHS-LC-biotin, solubilized, immunoprecipitated with control $\mathrm{IgG}$ or the $\mathrm{mAb}$ indicated, and fractionated by $4-12 \%$ gradient SDS-PAGE, under nonreducing (lanes 1-6) or reducing (lanes 7-12) conditions. Gels were transferred and probed with streptavidin-HRP and detected by ECL. Normal endoglin is identified as $160 \mathrm{kD}$, nonreduced, and $90 \mathrm{kD}$, reduced.

cDNA, a band of $197 \mathrm{bp}$ was detected in addition to the expected band of 338 bp (Fig. $2 \mathrm{~A}$ ). Primers E and F spanning exons 7-10 showed no differences in the $\mathrm{H} 19$ cDNA relative to other samples (Fig. $2 A$ ). Direct cycle sequencing of the purified PCR products obtained with primers $\mathrm{N}$ and $\mathrm{R}$, in both $5^{\prime}$ and $3^{\prime}$ directions, revealed that the $\mathrm{H} 19 \mathrm{cDNA}$ sequence was interrupted from 219-361 bp (Fig. 2 B). This corresponds to an in-frame deletion of exon 3 (141 bp) that generates a protein missing 47 amino acids between $\mathrm{T} 73$ and N 121.

Genomic DNA was isolated from normal placenta, H19 placenta, H19 HUVEC, and H31 PBL from the clinicallyaffected father of H19. PCR amplification and direct cycle sequencing of exon 3 and flanking intronic sequence revealed a 
G to A substitution in intron 3 in the $\mathrm{H} 19$ and $\mathrm{H} 31$ samples but not in the normal sample (Fig. 3). This destroys the invariant intronic/GT splice donor sequence such that splicing does not occur at this junction but at the next 5' GT splice site downstream (53). Exon 3 is thus spliced out along with the intron. PCR amplification and direct sequencing of exons 11, 12, and 13 using genomic DNA from $\mathrm{H} 19$ and $\mathrm{H} 31$ samples showed no additional mutation and confirmed that an intact transmembrane region should be present in the mutant protein (data not shown).

Characterization of a mutated endoglin protein in HHT family 9. Expression of endoglin at the cell surface was examined in the H19 HUVEC to test if mutant endoglin could act as a dominant negative, either as a homodimer, or heterodimer with wild-type endoglin. To maximize detection of a mutated protein, expression of endoglin was analyzed with mAb that recognize epitopes mapping to three distinct areas of the extracellular domain (46), as shown in Fig. 1. Quantitative flow cytometry revealed that $\mathrm{H} 19 \mathrm{HUVEC}$ expressed $46 \pm 6 \%$ surface endoglin relative to the control HUVEC with all of the four mAb tested (Fig. $4 A$ ), suggesting that only normal endoglin is present at the cell surface. The expression of $\alpha 5 \beta 1$ integrin and CD31 (PECAM) were unchanged, indicating there is a specific reduction in endoglin expression. When H19 HUVEC were labeled by surface biotinylation and analyzed by immunoprecipitation, only normal endoglin homodimers $(160 \mathrm{kD}$, nonreduced and $90 \mathrm{kD}$, reduced) were observed at the surface of H19 HUVEC and at reduced levels relative to normal. No mutant monomers nor heterodimers were detected on these cells with mAb P3D1 and CLE4 (Fig. 4 B).

Next, we analyzed these cells by metabolic labeling and im- munoprecipitation, to visualize newly synthesized normal and mutant proteins. Fully glycosylated endoglin (E; $160 \mathrm{kD}$ nonreduced, $90 \mathrm{kD}$ reduced) and a partially processed precursor $(\mathrm{P}$; $140 \mathrm{kD}$ nonreduced, $80 \mathrm{kD}$ reduced) were seen with both $\mathrm{H} 19$ and normal HUVEC (Fig. $5 A$ ). Quantitation by phosphorimager analysis confirmed that the fully glycosylated protein expressed in the $\mathrm{H} 19$ sample was reduced to $41 \pm 9 \%$ (Table I) in agreement with flow cytometry data (Fig. 4). Metabolic labeling also revealed a mutated form of endoglin (M) migrating as a homodimer of $130 \mathrm{kD}$ and as a monomer of $70 \mathrm{kD}$. Reactivity of the mutant protein with $\mathrm{mAb} \mathrm{P} 3 \mathrm{D} 1$ that recognizes an epitope between E26-G230 was 40\% of that observed with mAb CLE4 reactive with the COOH-terminal half of the extracellular domain, as visualized in Fig. 5 A. This is consistent with the finding that $\mathrm{H} 19$ has an exon 3 skip. Thus the polypeptide is $\sim 5 \mathrm{kD}$ shorter than the normal monomer; further reduction in apparent molecular mass is likely due to the loss of an $\mathrm{NH}_{2}$-linked glycosylation site in exon 3 and possibly inefficient glycosylation of $\mathrm{N} 121$ at position 1 of exon 4 (see Fig. 1). Western blot analysis of lysates from H19 versus normal HUVEC reveals normal endoglin migrating as a homodimer but no mutant protein (Fig. $5 \mathrm{~B}$ ). The level of normal endoglin dimer detected by Western blot in the H19 lysate was estimated to be $50 \%$ of normal from the ratio of densitometric units at equivalent protein concentration (Fig. $5 C$ ).

Since the mutant form of endoglin is only detected by metabolic labeling, both as monomer and dimer, it suggests that it is a transient species, and probably degraded intracellularly. When H19 HUVEC were analyzed by varying the labeling time ( 20 min to $4 \mathrm{~h}$; not shown) mutant and normal polypeptides were detected at $20 \mathrm{~min}$, whereas fully glycosylated $(E)$

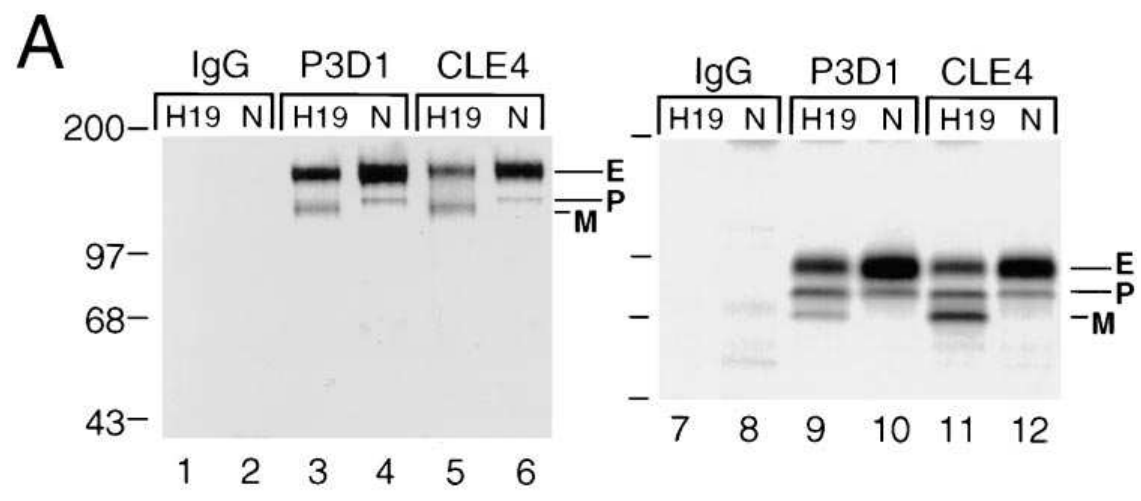

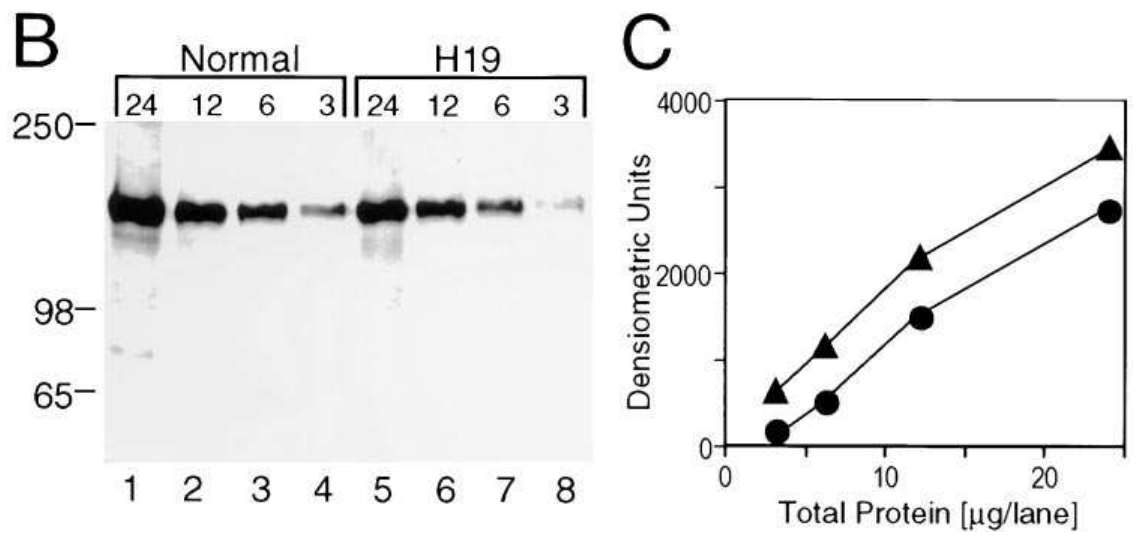

Figure 5. Identification of an intracellularly localized, transiently expressed mutant endoglin protein in H19 HUVEC. ( $A$ ) H19 and normal HUVEC were pulsed with $\left[{ }^{35} \mathrm{~S}\right] \mathrm{met}$ for $6 \mathrm{~h}$, lysed, immunoprecipitated and fractionated as described in Fig. 4 B. Gels were analyzed by fluorography. Mutated $(M)$ endoglin is visualized as a homodimer of $130 \mathrm{kD}$ (lanes 3 and 5) and as a monomer of $70 \mathrm{kD}$ (lanes 9 and 11). This is in addition to the normal homodimer of fully glycosylated endoglin $(E ; 160 \mathrm{kD})$ and monomer of $90 \mathrm{kD}$ seen with both $\mathrm{H} 19$ and normal HUVEC. Traces of partially processed precursor $(P)$ are detected as a homodimer of $140 \mathrm{kD}$ (more readily seen in lanes 4 and 6 ) and better resolved under reducing conditions as a monomer of $80 \mathrm{kD}$. (B) Quantitative Western blot analysis of Triton X-100 lysates (24-3 $\mu \mathrm{g}$ of protein per lane) from normal and H19 HUVEC was performed after fractionation by SDS-PAGE (6\%) and electrotransfer onto nitrocellulose filters. Using mAb CLE4, only endoglin homodimer is seen, with no detectable mutant. $(C)$ Densitometry analysis of this immunoblot $(\boldsymbol{\Lambda}$, normal HUVEC; $\bullet$, H19 HUVEC). 
Table I. Clinical and Molecular Data on 4 HHT1 Families Analyzed

\begin{tabular}{rccccc}
\hline Family number & Patient & HHT clinical diagnosis & PAVM in patient & Mutation* $^{*}$ & Surface endoglin expression $^{*}$ \\
\hline 9 & 19-newborn & No & Unscreened & Exon 3 skip & $41 \pm 9 \%$ \\
9 & 31-father & Yes & Yes & Exon 3 skip & $53 \pm 8 \%$ \\
21 & 65-adult & Yes & Unscreened & Exon 8, $\mathrm{S}_{1}$ & $46 \pm 7 \%$ \\
25 & 74-adult & Yes & Yes & Exon 8, $\mathrm{I}_{1}$ & $46 \pm 19 \%$ \\
39 & 119-adult & Yes & Yes & Exon 10, $\mathrm{S}_{1}$ & $42 \pm 9 \%$ \\
\hline
\end{tabular}

*Exon 3 skip described in the current study. Other mutations reported previously (McAllister et al., 35): Exon 8 S , a T to A substitution at position 1050 creating a stop at codon $350(\Delta 350)$; Exon $8 \mathrm{I}_{1}$, a 1-bp insertion at position 1111 causing a frameshift that leads to a premature stop at codon 371 $(\Delta 371)$; Exon $10 \mathrm{~S}_{1}$, a $\mathrm{C}$ to $\mathrm{T}$ substitution at position 1414 creating a stop at codon $472(\Delta 472)$. ${ }^{\ddagger}$ Levels of surface endoglin expression were determined by metabolic labeling with $\left.{ }^{35} \mathrm{~S}\right]$ met and quantitative immunoprecipitation in HUVEC or blood derived activated monocytes relative to controls $($ mean $\pm S D)$. Each experiment included four sets of data $(2 \mathrm{mAb}$, reduced and nonreduced conditions) and pixel values for the $\mathrm{E}$ band were quantitated by phosphorimager and the patient/control ratio was calculated for each lane. The average for all values derived from 1 to 3 experiments is shown. ${ }^{\S}$ PAVM have been detected in other members of this family.

endoglin appeared at $1.5 \mathrm{~h}$. A minimum labeling time of $3.5 \mathrm{~h}$ was required to see the maximal difference between fully processed mutant and normal endoglin.

Next, we established that the mutant form seen in H19, was also expressed in the clinically affected father (H31), by analyzing endoglin expression using metabolic labeling of monocytes derived from peripheral blood and activated by adherence to plastic. A mutant protein was seen in $\mathrm{H} 31$, which migrated similarly to that observed in H19 HUVEC and that was not detectable in control samples (Fig. 6). Fully glycosylated normal endoglin $(E)$ and its partially processed precursor $(P)$, were observed in monocytes and endothelial cells of patient and control samples. The expression of normal endoglin (E) was $53 \pm 8 \%$ in $\mathrm{H} 31$ monocytes compared with normal (Table I). Together, these data indicate that the transient, intracellular mutant form of endoglin seen in H19 is inherited, and that family 9 is an HHT1 family.

Reduced endoglin expression and lack of detectable mutants in three clinically affected HHT1 patients. The mutant protein ex-

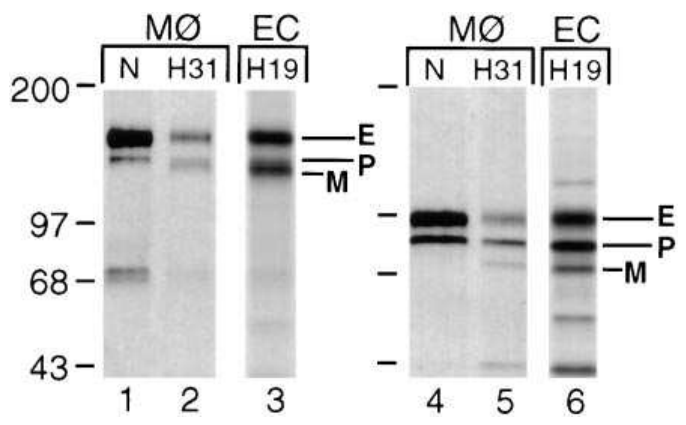

Figure 6. Mutant endoglin protein is also detected in H31. PBMC of $\mathrm{H} 31$ the father of $\mathrm{H} 19$, or normal $(N)$ were activated by adherence to plastic for $24 \mathrm{~h}$. Activated monocytes $(M \varnothing)$ were labeled with $\left.{ }^{[35} \mathrm{S}\right] \mathrm{met}$ for $4-5 \mathrm{~h}$ and processed as described in Fig. $5 \mathrm{~A}$. Immunoprecipitation with $\mathrm{mAb}$ P4A4 reveals endoglin homodimers $(130 \mathrm{kD})$, and monomers $(70 \mathrm{kD})$ of mutated $(M)$ endoglin in monocytes (lanes 2 and 5) from the affected father and HUVEC ( $E C$; lanes 3 and 6$)$ from his child. In addition, the normal endoglin $(E)$ homodimer of $160 \mathrm{kD}$ and monomer of $90 \mathrm{kD}$, as well as the precursor $(P)$ homodimer of $140 \mathrm{kD}$ and monomer of $80 \mathrm{kD}$, are seen in all the samples. pressed in HHT family 9 represents the first identified in HHT1; it is, however, only detectable by metabolic labeling and likely degraded intracellularly. Normal endoglin was reduced by half at the cell surface and in cell extracts, suggesting that HHT1 might be associated with a decrease in the level of functional endoglin rather than with a dominant negative effect of the mutant protein. To establish if mutations creating premature stop codons code for truncated proteins that could function as dominant negatives, we analyzed endoglin expression in activated monocyte samples derived from three clinically affected HHT1 patients. These patients: H65, H74, and H119 were described previously, and carry known mutations in exons 8 and 10 , corresponding to $\Delta 350, \Delta 371$, and $\Delta 472$ (35), (Fig. 1). Activated monocytes from patients were metabolically labeled and analyzed in parallel with normal monocytes by immunoprecipitation using mAb P3D1 and P4A4. There were no detectable truncated forms of endoglin, and normal endoglin was expressed at half levels relative to control in all cases (Fig. 7 and Table I). Conditioned media of samples from patient $\mathrm{H} 119$ were also tested for the presence of a secreted form of mutant protein; none were detected (not shown). Mutated forms of endoglin, if expressed at all, appear to be transient and could not significantly interfere with the function of endoglin at the cell surface.

H118 and H22 represent two clinically affected HHT patients, which were analyzed in parallel with H119, and two normal controls; all patients in this experiment were women ranging in age from 22 to $49 \mathrm{yr}$ (Fig. 7, lanes 5-9). H118 and H22 were found to have normal levels of endoglin $(91 \pm 16 \%$ and $84 \pm 19 \%$ ) relative to the mean of the two controls. These values represent variations within normal values of endoglin and are clearly distinct from that of the HHT1 patient, H119 (42士 9\%). H118 and H22 are likely HHT2 patients but this will be confirmed by mutation analysis.

HHT1 mutants expressed in COS-1 cells do not form heterodimers and are not secreted. The expression level of endoglin in activated monocytes is low compared with HUVEC. Thus, to further establish the cellular localization and confirm the transient nature of truncated forms of endoglin, we engineered mammalian expression constructs with stop codons in exons $7(\Delta 276)$ and $11(\Delta 517)$ of human endoglin corresponding to two identified mutations in HHT1 (12) (see Methods and Fig. 1). These were overexpressed in COS-1 cells alone or 


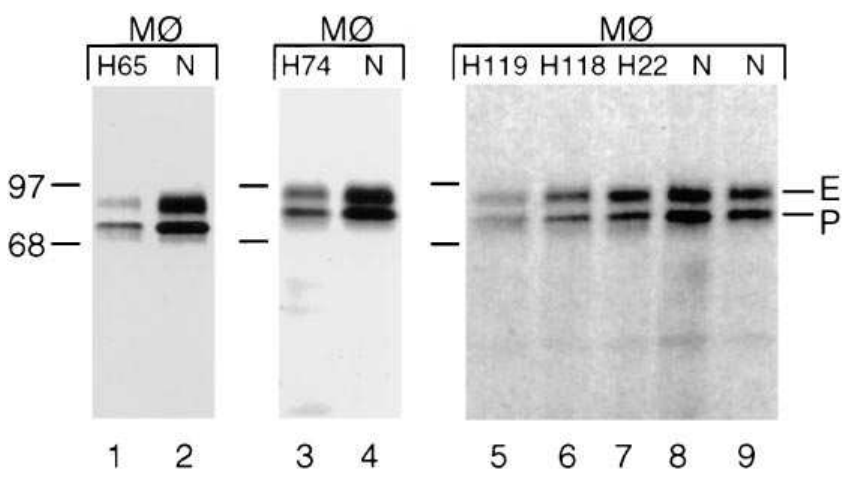

Figure 7. Truncated proteins are not detectable in patient samples from clinically affected HHT1 individuals. Endoglin expression was analyzed in samples of three HHT1 patients $(H 65, H 74$, and H119) with premature stop codons $\Delta 350, \Delta 371$, and $\Delta 472$, respectively, as shown in Fig. 1. Activated monocytes $(M \varnothing)$ from these three patients and control donors prepared in parallel, were labeled with $\left[{ }^{35} \mathrm{~S}\right] \mathrm{met}$ for $4 \mathrm{~h}$ and analyzed as in Fig. 6. Two additional HHT patients (H118 and $H 22$ ) were included in the H119 experiment. Immunoprecipitation was performed with both mAb P3D1 and P4A4 and analyzed under reduced and nonreduced conditions. One set of data from three different experiments (one $\mathrm{mAb}$ and reduced conditions) is illustrated. Equivalent cpm (estimated by TCA precipitation) were loaded for patients and matched controls in each experiment. Total radioactivity in the normal fully glycosylated endoglin $(E)$ band was quantitated by phosphorimager and pixel values were: lane 1,11,970 versus lane 2,29,743; lane 3,31,990 versus lane 4,53,308; lane 5, 1,430 versus lane $6,4,306$; lane 7,4,700; lane $8,4,562$; lane $9,4,033$. in combination with full length endoglin (END) by transient transfection. Transfected cells were labeled with [ $\left.{ }^{35} \mathrm{~S}\right] \mathrm{met}$ and analyzed by immunoprecipitation. Fully glycosylated endoglin (E) and partially processed precursor $(P)$ were seen as 80 and $70 \mathrm{kD}$ bands under reducing conditions (Fig. $8 A$, lanes 2-4), and at 150 and $130 \mathrm{kD}$ under nonreducing conditions (Fig. $8 \mathrm{~A}$, lanes 11-13) in all cells transfected with END but not with empty vector controls (Fig. $8 A$, lanes 1 and 10 ). The truncated forms, $\Delta 276$ and $\Delta 517$, were expressed as 32 and $60 \mathrm{kD}$ proteins under reducing conditions (Fig. $8 A$, lanes 5 and 6 ) and are still detectable in extracts when cotransfected with END (Fig. $8 A$, lanes 3 and 4 ). Analysis of the conditioned media reveals that neither $\Delta 276$ nor $\Delta 517$ were detectable as secreted forms when compared with the vector control (Fig. $8 \mathrm{~A}$, lanes 7-9), despite their expression in the cell lysates. Under nonreducing conditions, $\Delta 276$ is not detectable in cell lysates (Fig. 8 $A$, lane 14 ), whereas $\Delta 517$ is mostly monomeric and runs at 54 $\mathrm{kD}$, yet some dimeric $\Delta 517$ is also visible (Fig. $8 A$, lane 15 ).

Surface labeling of transfected cells with biotin indicated that only normal full-length endoglin was detected as $85 \mathrm{kD}$ monomer and $150 \mathrm{kD}$ dimer under reducing and nonreducing conditions respectively (Fig. 8 B, lanes $2-4$ and 7 and 8 ). $\Delta 276$ and $\Delta 517$ were not expressed on the cell surface and did not form heterodimers indicating that these truncated forms of endoglin are exclusively expressed intracellularly.

H19 HUVEC do not show an altered response to TGF- $\beta 1$. Since endoglin normally associates with T $\beta R$-II and T $\beta R$-I in the presence of TGF- $\beta 1$, we tested the ability of H19 HUVEC to bind and respond to this ligand. To visualize receptor com-
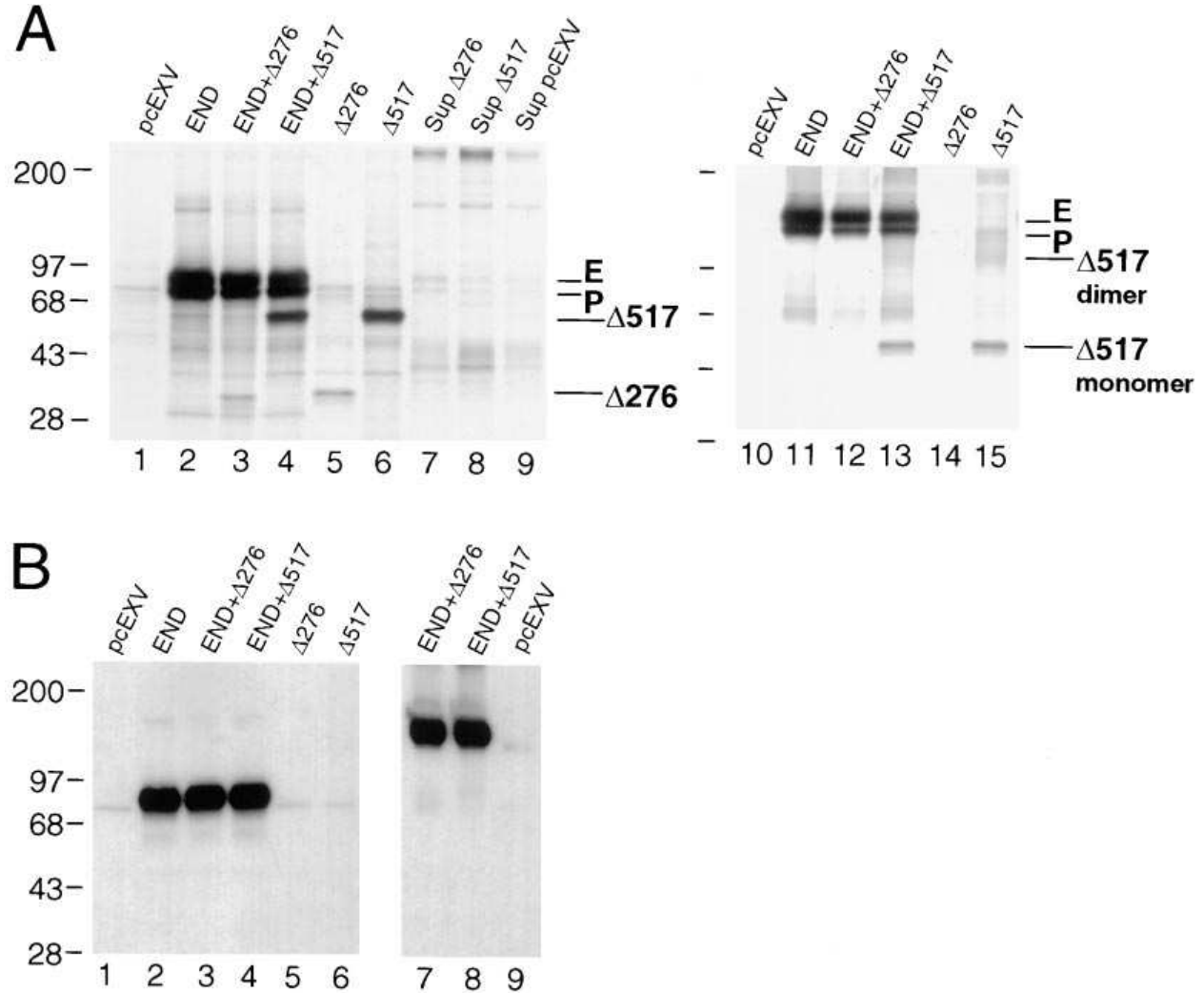

Figure 8. Expression of truncated forms of endoglin in COS-1 cells. Expression constructs $\Delta 276$ and $\Delta 517$ (as illustrated in Fig. 1) were introduced into COS-1 cells alone or in combination with full-length endoglin $(E N D)$ by transient transfection using DEAE-dextran. $(A)$ Transfected cells were labeled with $\left[{ }^{35} \mathrm{~S}\right] \mathrm{met}$ for $4 \mathrm{~h}$ and analyzed as in Fig. 5 A. Immunoprecipitation with $\mathrm{mAb}$ P3D1 shows fully glycosylated endoglin $(E)$ and the partially processed precursor $(P)$ as $80 \mathrm{kD}$ and $70 \mathrm{kD}$ (lanes 2-4) under reducing conditions, and 150 and $130 \mathrm{kD}$ under nonreducing conditions (lanes 11-13) not seen in cells transfected with pcEXV vector control (lanes 1 and 10 ). $\Delta 276$ and $\Delta 517$ are detected as 32 and $60 \mathrm{kD}$ under reducing conditions (lanes 5 and 6 ) and are still detectable in lysates when cotransfected with END (lanes 3 versus 5 and lanes 4 versus 6$)$. Total conditioned media from each transfection were immunoprecipitated with $\mathrm{mAb}$ P3D1 and P4A4. All of the eluted material was fractionated both reduced and nonreduced. Reducing conditions are shown in lanes 7-9,

which reveal no specific band compared with the empty vector control. (B) Immunoprecipitates of lysates from transfected cells surface labeled with biotin show only monomeric full-length endoglin detected as 85 and $150 \mathrm{kD}$ under reducing and nonreducing conditions, respectively (lanes $2-4$ and 7 and 8 ). 


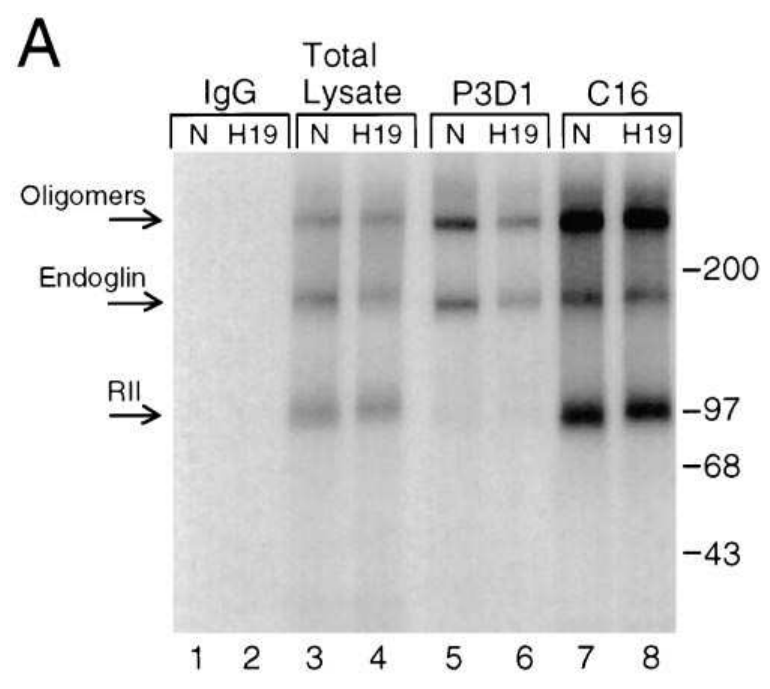

B

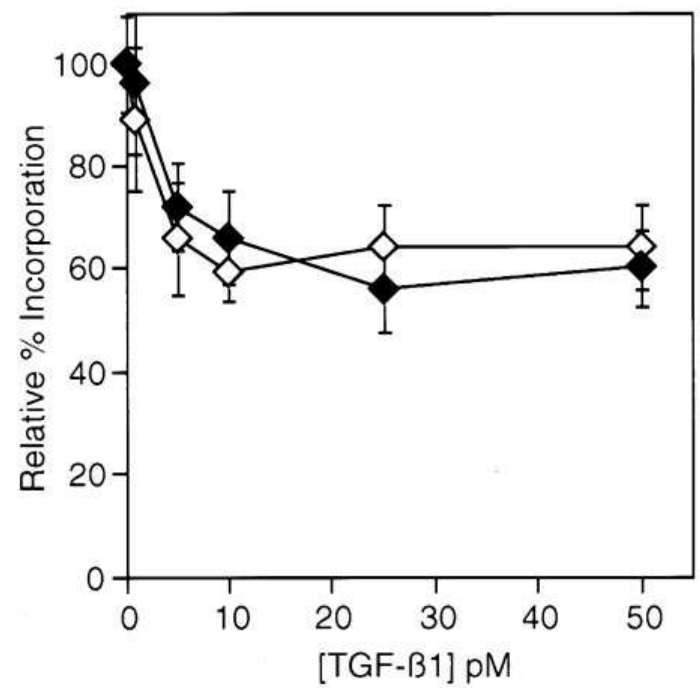

Figure 9. TGF- $\beta 1$ response of H19 HUVEC relative to normal. (A) $\mathrm{H} 19$ and control HUVEC were incubated for $4 \mathrm{~h}$ with $100 \mathrm{pM}$ $\left[{ }^{125} \mathrm{I}\right]$ TGF- $\beta 1$, cross-linked with DSS and solubilized with Triton $\mathrm{X}-100$. Aliquots of total lysates with equivalent protein concentrations, were subjected to immunoprecipitation with control IgG, mAb P3D1, or polyclonal antibody C16 to TGF- $\beta$ Receptor II (RII). When fractionated by SDS-PAGE 4-12\% gradient gel, under nonreducing conditions, the total lysates reveal endoglin dimers and oligomers and RII crosslinked to TGF- $\beta 1$ (lanes 3 and 4). mAb P3D1 (lanes 5 and 6 ) immunoprecipitates endoglin bands with a trace of RII while C16 (lanes 7 and 8 ) clearly brings down RII associated with endoglin. Immunoprecipitations are specific as seen with the control IgG lanes 1 and 2. (B) Inhibition of proliferation by TGF- $\beta 1$ of H19 HUVEC $(\diamond)$ relative to normal $(\diamond)$. Cells were seeded at 5,000 cells per well and incubated with increasing concentrations of TGF- $\beta 1$ ranging from 0 to $50 \mathrm{pM}$ for $48 \mathrm{~h}$. A $6 \mathrm{~h}$ pulse with $\left[{ }^{3} \mathrm{H}\right]$ thymidine $(1 \mu \mathrm{Ci} /$ well $)$ was performed and the percentage incorporation relative to control (no TGF- $\beta 1$ ) is estimated for each concentration. Illustrated here is the mean of two independent experiments where $\mathrm{H} 19$ was analyzed in parallel with normal HUVEC, and the SD was calculated from the relative error of each experiment $(n=3$ and $n=6)$. plexes, H19 and control HUVEC were labeled with [ ${ }^{[25}$ I]TGF$\beta 1$, incubated with DSS cross-linker, and solubilized. Analysis of total lysates (Fig. $9 \mathrm{~A}$, lanes 1 and 2 ) revealed proteins of $>200,180$ and $95 \mathrm{kD}$ cross-linked to TGF- $\beta 1$ that correspond to endoglin oligomers, dimers and T $\beta$ R-II respectively. Immunoprecipitation of endoglin with mAb P3D1 (Fig. 9 A, lanes 5 and 6 ) reveals the endoglin oligomers and dimers and a trace of associated T $\beta \mathrm{R}-\mathrm{II}$; less labeled endoglin was observed in H19 relative to normal samples, as quantitated by phosphorimager analysis, suggesting that the total amount of endoglin cross-linked to TGF- $\beta 1$ is less in the H19 cells. Immunoprecipitation with $\mathrm{C} 16$ antibody to T $\beta \mathrm{R}$-II demonstrates clearly the association of this receptor with endoglin dimers and oligomers (lanes 7 and 8 ); furthermore equal amounts of endoglin and T $\beta$ R-II were observed in both H19 and normal samples suggesting that the number of TGF- $\beta 1$ receptor complexes are the same in HHT1 patients and normal. TßR-I was visible in lanes 3 and 4 and 7 and 8 after longer exposures indicating that it is also expressed as a component of the receptor complex in HHT and normal cells. Specificity of the reactions was confirmed by the IgG controls (lanes 1 and 2). Thus, no significant differences in TGF- $\beta 1$ receptor complexes were observed between H19 and normal HUVEC.

As TGF- $\beta 1$ normally inhibits the proliferation of HUVEC in culture $(54,55)$, we compared the H19 HUVEC to normal for their proliferative response to this ligand (Fig. $9 \mathrm{~B}$ ). Proliferation, as measured by $\left[{ }^{3} \mathrm{H}\right]$ thymidine incorporation, was estimated for each HUVEC at $0,5,10,25$, and $50 \mathrm{pM}$ TGF- $\beta 1$ and the percentage incorporation relative to that observed in the absence of ligand is reported. Proliferation was inhibited by TGF- $\beta 1$ to the same degree in H19 and normal HUVEC (Fig. $9 B$ ).

\section{Discussion}

Endoglin is mutated in HHT1. However, how these mutations might act to disrupt protein function is unknown. As this disease is dominantly inherited, and mutations leading to premature stop codons were predominantly reported, McAllister et al. (35) proposed a dominant-negative model involving the expression of mutated proteins that can disrupt the normal endoglin function. Such a model requires expression of mutant proteins that should be detectable in patients. As endoglin is an integral plasma membrane glycoprotein, mutated forms should either be expressed at the cell surface or secreted in order to interfere with the normal homodimer. We now report the characterization of endoglin protein in HUVEC from a newborn with a family history of HHT and in activated monocytes from peripheral blood of clinically diagnosed HHT1 patients. We first describe a new endoglin mutation, a $\mathrm{G}$ to $\mathrm{A}$ substitution destroying the invariant/gt splice donor sequence in the $5^{\prime}$ end of intron 3 that leads to an exon 3 skip in family 9. Such a mutation is an excellent candidate for a dominant-negative model, as the protein is expressed with an intact transmembrane region and could disrupt the function of normal endoglin at the cell surface. However, this mutant protein was only observed by metabolic labeling indicating a transient intracellular expression. Analysis of activated monocytes from 3 HHT1 patients with mutations leading to premature stop codons in exons 8 and 10, revealed no detectable mutant proteins. In addition, overexpression in COS- 1 cells of two other known HHT1 mutant forms with stop codons in exons 7 
$(\Delta 276)$ and $11(\Delta 517)$ respectively, showed that these proteins were only present intracellularly and were not secreted. These results suggest that mutant forms of endoglin when expressed, do not heterodimerize with wild-type endoglin and are probably degraded intracellularly. Thus, a dominant negative model based on expression at the cell surface or secretion of mutant forms is not compatible with our analysis of the HHT1 mutants.

11 mutations have been sequenced to date and 8 of these introduce premature termination codons in the extracellular domain of endoglin $(12,35,36)$. We have analyzed 5 of these 8 truncation mutations in this study, either directly in patient samples or in a mammalian expression system. Based on our study, all truncation mutations are likely to code for transiently expressed proteins that are not secreted. The exon 3 skip reported here, and a smaller 39-bp deletion within exon 7 described previously (12), both generate in-frame deletions at the cDNA level. This 39 bp deletion is likely to be expressed as a misfolded protein that is also retained intracellularly. Other in-frame deletions could also be translated as transiently expressed species. A missense mutation in exon 4 at codon 160 (A to D) was reported recently (36). It is necessary to determine if such a mutant protein is expressed and if so, whether it might be nonfunctional because of an alteration in a key amino acid.

Our data suggest that the reduced expression of functional endoglin is a primary defect in HHT1. It is reported here in four families with defined endoglin mutations (Table I). 11 additional HHT families with a history of PAVM and/or CAVM, have also revealed reduced endoglin expression, with no detectable mutant protein. Genetic analysis should confirm the mutation present in these families and the value of the protein analysis in samples from clinically diagnosed patients and in potential HHT1 patients. It is also necessary to study a much larger number of HHT families to determine genotype/phenotype correlations and to confirm the current trend of an association between HHT1 and predisposition to PAVM and CAVM.

H19 HUVEC, expressing 50\% endoglin, bind TGF- $\beta 1$ normally and endoglin association with T $\beta R$-II and T $\beta R$-I is unchanged. There is an $\sim 100$-fold ratio of endoglin to T $\beta$ R-II on the surface of normal endothelial cells, thus it is not surprising to find unaltered receptor complexes in HHT1 cells of H19 HUVEC. Inhibition of proliferation in response to TGF- $\beta 1$ was also not influenced by a $50 \%$ decrease in endoglin expression. Preliminary data suggest that fibronectin production in response to TGF- $\beta 1$ was not altered either in these cells. Overexpression of endoglin in the U937 monocytic cell line was shown to interfere with several TGF- $\beta 1$ responses including inhibition of proliferation and stimulation of fibronectin production, suggesting that endoglin can indeed alter several TGF- $\beta 1$ responses (24). However, endothelial cell responses modified by a reduction in the level of functional endoglin and implicated in the pathology of HHT1 have yet to be identified, as the classical responses tested were unaltered.

TGF- $\beta 1$ has been implicated in vascular development as supported by the observation that $50 \%$ of TGF- $\beta 1$ null mice died from a defect in yolk sac vasculogenesis manifested by improper interactions between endothelial and mesenchymal layers (56). Arteriovenous malformations with their convoluted vessels also suggest inadequate interactions between the endothelial cells having less endoglin and the smooth muscle cells being produced in an attempt to arterialize the veins to sustain the increased blood flow associated with the lack of an intervening capillary bed $(1,3)$. As TGF- $\beta 1$ regulates matrix production and assembly, integrin expression, and the programmed interaction between endothelial and smooth muscle cell layers, it is likely that some of these responses are altered in HHT. Coculture of these cell types might be essential to identify the consequences of a reduction in endoglin on vasculogenesis.

The identification of ALK-1 as the gene mutated in HHT2 families (15) raises the possibility that a different receptor complex might also be implicated in the regulation of vessel formation. Such a complex might modulate responses which are distinct from those mediated by the ALK-5 containing TGF- $\beta$ receptor complex. ALK- 1 has also been described as an orphan receptor, as its true physiological ligand has not been identified. It is interesting to speculate that endoglin might be an essential coreceptor for this ligand of ALK-1, which would be implicated in vascular development.

Further characterization of the role of endoglin in TßRII/ ALK-5 complexes, and study of endoglin interaction with ALK-1 and its downstream effectors might greatly increase our knowledge of the mechanisms by which TGF- $\beta 1$ and potentially other ligands of the same family regulate vascular development. Ultimately, this would provide insight into how mutations in genes essential to these pathways lead to the generation of arteriovenous malformations ranging from telangiectases to PAVM.

Note added in proof: After this manuscript was submitted, a review paper on HHT was published which mentions seven new mutations in endoglin, two of which were associated with no detectable mRNA (57). This supports the data presented in this paper and our model of reduced expression of functional endoglin being the primary defect in HHT1.

\section{Acknowledgments}

We gratefully acknowledge all the patients who participated in the study and the support of the HHT Foundation International. We thank Dr. C. Bernabeu for providing the expression construct END, Dr. S. Pichuantes for $\Delta 276$ and $\Delta 517$ PCR products, Dr. S. Kumar for mAb CLE4, Dr. E.A. Wayner for mAb P3D1 and P4A4 and Dr. C. Shovlin for exon 3 primer sequences. We are also grateful to A. Bourdeau for establishing the HHT data base and for helpful discussions, Dr. S. Grinstein and J. Butler for technical advice with preparing activated monocytes and helping to obtain control blood samples, M. Hui and Dr. J. Dunn from Visible Genetics Inc. for guidance with automated cycle sequencing and use of the Microgeneblaster ${ }^{\circledR}$ and Dr. R. Gaedigk for technical advice on cycle sequencing, L. Gunaratnam for help with the macrophage cultures, and A. Greaves for assistance with flow cytometry. We would like to thank Dr. M. Brilliant for his insightful review of the manuscript.

This work was supported by grants from the Medical Research Council of Canada and Heart and Stroke Foundation of Ontario and by financial support from Visible Genetics Inc. for mutation analysis (M. Letarte). R.I. White is supported in part by funding from the Josephine Laurence Hopkins and the Orinoco Foundations. J. Wrana is an MRC Scholar, and M. Letarte is a Terry Fox Research Scientist of the National Cancer Institute of Canada.

\section{References}

1. Guttmacher, A.E., D.A. Marchuk, and R.I.J. White. 1995. Hereditary hemorrhagic telangiectasia. N. Engl. J. Med. 333:918-924. 
2. Plauchu, H., J.-P. de Chadaverian, A. Bideau, and J.-M. Robert. 1989. Age-related clinical profile of hereditary hemorrhagic telangiectasia in an epidemiologically recruited population. Am. J. Med. Genet. 32:291-297.

3. Braverman, I.M., A. Keh, and B.S. Jacobson. 1990. Ultrastructure and three-dimensional organization of the telangiectases of hereditary hemorrhagic telangiectasia. J. Investig. Dermatol. 95:422-427.

4. Wirth, J.A., J.S. Pollak, and R.I. White, Jr. 1996. Pulmonary arteriovenous malformations. Curr. Pulmonol. Crit. Care Med. 17:261-298.

5. Shovlin, C.L., A.R. Winstock, A.M. Peters, J.E. Jackson, and J.M.B. Hughes. 1995. Medical complications of pregnancy in hereditary haemorrhagic telangiectasia. Q. J. Med. 88:879-887.

6. Kikuchi, K., M. Kowada, and H. Sasajima. 1994. Vascular malformations of the brain in hereditary hemorrhagic telangiectasia (Rendu-Osler-Weber disease). Surg. Neurol. 41:374-380.

7. Garcia-Monaco, R., W. Taylor, G. Rodesch, H. Alvarez, P. Burrows, P. Coubes, and P. Lasjaunias. 1995. Pial arteriovenous vistula in children as presenting manifestation of Rendu-Osler-Weber disease. Neuroradiology. 37:60-64.

8. Scully, R.E., E.J. Mark, W.F. McNeely, S.H. Ebeling, and L.D. Phillips. 1997. Case records of the Massachusetts general hospital (Case 7-1997). N. Engl. J. Med. 336:641-648.

9. McDonald, M.T., K.A. Papenberg, S. Ghosh, A.A. Glatfelter, B.B. Biesecker, E.A. Helmbold, D.S. Markel, A. Zolotor, W.C. McKinnon, J.L. Vanderstoep, et al. 1994. A disease locus for hereditary haemorrhagic telangiectasia maps to chromosome 9q33-34. Nat. Genet. 6:197-204.

10. Shovlin, C.L., J.M.B. Hughes, E.G.D. Tuddenham, I. Temperley, Y.F.N. Perembelon, J. Scott, C.E. Seidman, and J.G. Seidman. 1994. A gene for hereditary haemorrhagic telangiectasia maps to chromosome 9q3. Nat. Genet. 6:205-209.

11. Fernandez-Ruiz, E., S. St-Jacques, T. Bellon, M. Letarte, and C. Bernabeu. 1993. Assignment of the human endoglin gene (END) to chromosome 9q34-qter. Cytogenet. Cell Genet. 64:204-207.

12. McAllister, K.A., K.M. Grogg, D.W. Johnson, C.J. Gallione, M.A. Baldwin, C.E. Jackson, E.A. Helmbold, D.S. Markel, W.C. McKinnon, J. Murrell, et al. 1994. Endoglin, a TGF- $\beta$ binding protein of endothelial cells is the gene for hereditary haemorrhagic telangiectasia type 1. Nat. Genet. 8:345-351.

13. Vincent, P., H. Plauchu, J. Hazan, S. Fauré, J. Weissenbach, and J. Godet. 1995. A third locus for hereditary haemorrhagic telangectasia maps to chromosome 12q. Hum. Mol. Genet. 4:945-949.

14. Johnson, D.W., J.N. Berg, C.J. Gallione, K.A. McAllister, J.P. Warner, E.A. Helmbold, D.S. Markel, C.E. Jackson, M.E.M. Porteus, and D.A. Marchuk. 1995. A second locus for hereditary hemorrhagic telangiectasia maps to chromosome 12. Genet. Res. 5:21-28.

15. Johnson, D.W., J.N. Berg, M.A. Baldwin, C.J. Gallione, I. Marondel, S. Yoon, T.T. Stenzel, M. Speer, M.A. Pericak-Vance, A. Diamond, et al. 1996. Mutations in the activin receptor-like kinase 1 gene in hereditary hemorrhagic telangiectasia type 2. Nat. Genet. 13:189-195.

16. Piantanida, M., E. Buscarini, C. Dellavecchia, A. Minelli, A. Rossi, L. Buscarini, and C. Danesino. 1996. Hereditary haemorrhagic telangiectasia with extensive liver involvement is not caused by either HH1 and HHT2. J. Med. Genet. 33:441-443.

17. McAllister, K.A., F. Lennon, B. Bowles-Biesecker, W.C. McKinnon, E.A. Helmbold, D.S. Markel, C.E. Jackson, A.E. Guttmacher, M.A. PericakVance, and D.A. Marchuk. 1994. Genetic heterogeneity in hereditary haemorrhagic telangiectasia: possible correlation with clinical phenotype. J. Med. Genet. 31:927-932.

18. Heutink, P., T. Haitjema, G.J. Breedveld, B. Janssen, L.A. Sandkuijl, C.J.M. Bontekoe, C.J.J. Westerman, and B.A. Oostra. 1994. Linkage of hereditary haemorrhagic telangiectasia to chromosome $9 \mathrm{q} 34$ and evidence for locus heterogeneity. J. Med. Genet. 31:933-936.

19. Berg, J.N., A.E. Guttmacher, D.A. Marchuk, and M.E.M. Porteous. 1996. Clinical heterogeneity in hereditary haemorrhagic telangiectasia: are pulmonary arteriovenous malformations more common in families linked to endoglin? J. Med. Genet. 33:256-257.

20. Gougos, A., and M. Letarte. 1990. Primary structure of endoglin, an RGD-containing glycoprotein of human endothelial cells. J. Biol. Chem. 265: 8361-8364.

21. Lastres, P., T. Bellon, C. Cabanas, F. Sanchez-Madrid, A. Acevedo, A. Gougos, M. Letarte, and C. Bernabeu. 1992. Regulated expression on human macrophages of endoglin, an RGD containing surface antigen. Eur. J. Immunol. 22:393-397.

22. Cheifetz, S., T. Bellón, C. Calés, S. Vera, C. Bernabeu, J. Massagué, and M. Letarte. 1992. Endoglin is a component of the transforming growth factor- $\beta$ receptor system in human endothelial cells. J. Biol. Chem. 267:19027-19030.

23. Zhang, H.W., A.R.E. Shaw, A. Mak, and M. Letarte. 1996. Endoglin is a component of the TGF- $\beta$ receptor complex of human pre-B leukemic cells. $J$. Immunol. 156:565-573.

24. Lastres, P., A. Letamendia, H. Zhang, C. Rius, N. Almendro, L.A. Lopez, C. Langa, A. Fabra, M. Letarte, and C. Bernabeu. 1996. Endoglin modulates cellular responses to TGF- $\beta 1$. J. Cell Biol. 133:1109-1121.

25. RayChaudury, A., and P.A. D'Amore. 1991. Endothelial cell regulation by TGF-beta. J. Cell. Biochem. 47:224-229.

26. Folkman, J., and P.A. D'Amore. 1996. Blood vessel formation: what is its molecular basis? Cell. 87:1153-1155.
27. Wrana, J.L., L. Attisano, R. Wieser, F. Ventura, and J. Massagué. 1994. Mechanisms of activation of the TGF- $\beta$ receptor. Nature (Lond.). 370:341-347.

28. Massagué, J., L. Attisano, and J.L. Wrana. 1994. The TGF- $\beta$ family and its composite receptors. Trends Cell Biol. 4:172-178.

29. Eppert, K., S.W. Sherer, H. Ozcelik, R. Pirone, P. Hoodless, H. Kim, L.C. Tsui, B. Bapat, S. Gallinger, I.L. Andrulis, et al. 1996. MADR2 maps to $18 \mathrm{q} 21$ and encodes a TGF $\beta$-regulated MAD-related protein that is functionally mutated in colorectal carcinoma. Cell. 86:543-552.

30. Attisano, L., J.L. Wrana, E. Montalvo, and J. Massagué. 1996. Activation of signaling by the activin receptor complex. Mol. Cell. Biol. 16:1066-1073.

31. Macías-Silva, M., S. Abdollah, P.A. Hoodless, R. Pirone, L. Attisano, and J.L. Wrana. 1996. MADR2 is a substrate of the TGF $\beta$ receptor and its phosphorylation is required for nuclear accumulation and signalling. Cell. 87: 1215-1224.

32. Derynck, R., W.M. Gelbart, R.M. Harland, C.-H. Heldin, S.E. Kern, J Massagué, D.A. Melton, M. Mlodzik, R.W. Padgett, A.B. Roberts, et al. 1996. Nomenclature: vertebrate mediators of TGF $\beta$ family signals. Cell. 87:173

33. Attisano, L., J. Cárcamo, F. Ventura, F.M.B. Weis, J. Massagué, and J.L. Wrana. 1993. Identification of human activin and TGF- $\beta$ type I receptors that form heteromeric kinase complexes with type II receptors. Cell. 75:671-680.

34. ten Dijke, P., H. Yamashita, H. Ichijo, P. Franzen, M. Laiho, K. Miyazono, and C.-H. Heldin. 1994. Characterization of the type I receptors for transforming growth factor $\beta$ receptor-like and activin. Science (Wash. DC). 264: 101-104.

35. McAllister, K.A., M.A. Baldwin, A.K. Thukkani, C.J. Gallione, J.N. Berg, M.E. Porteus, A.E. Guttmacher, and D.A. Marchuk. 1995. Six novel mutations in the endoglin gene in hereditary hemorrhagic telangiectasia type suggest a dominant-negative effect of receptor function. Hum. Mol. Genet. 4: 1983-1985.

36. Yamaguchi, H., H. Azuma, T. Shigekiyo, and H. Inoue. 1997. A novel missense mutation in the endoglin gene in hereditary hemorrhagic telangiectasia. Thromb. Haemostasis. 77:243-247.

37. Gougos, A., and M. Letarte. 1988. Identification of a human endothelial cell antigen with monoclonal antibody $44 \mathrm{G} 4$ produced against a pre-B leukemic cell line. J. Immunol. 141:1925-1933.

38. Burrows, F.J., E.J. Derbyshire, P.L. Tazzari, P. Amlot, A.F. Gazdar, S.W. King, M. Letarte, E.S. Vitetta, and P.E. Thorpe. 1995. Up-regulation of endoglin on vascular endothelial cells in human solid tumors: implications for diagnosis and therapy. Clinical Cancer Res. 1:1623-1634.

39. St-Jacques, S., U. Cymerman, N. Pece, and M. Letarte. 1994. Molecular characterization and in situ localization of murine endoglin reveal that it is a transforming growth factor- $\beta$ binding protein of endothelial and stromal cells. Endocrinology. 134:2645-2657.

40. Bellón, T., A. Corbi, P. Lastres, C. Calés, M. Cebrián, S. Vera, M. Chefeitz, J. Massagué, M. Letarte, and C. Bernabeu. 1993. Identification and expression of two forms of the human transforming growth factor- $\beta$-binding protein endoglin with distinct cytoplasmic regions. Eur. J. Immunol. 23:23402345

41. Hoodless, P.A., T. Haerry, S. Abdollah, M. Stapleton, M.B. O'Connor, L. Attisano, and J.L. Wrana. 1996. MADR1, a MAD-related protein that functions in BMP2 signaling pathways. Cell. 85:489-500.

42. Quackenbush, E.J., and M. Letarte. 1985. Identification of several cell surface proteins of non-T, non-B acute lymphoblastic leukemia by using monoclonal antibodies. J. Immunol. 134:1276-1285.

43. Gougos, A., and M. Letarte. 1988. Biochemical characterization of the 44G4 antigen from the HOON pre-B leukemic cell line. J. Immunol. 141:1934 1940 .

44. Letarte, M., A. Greaves, and S. Vera. 1995. CD105 (endoglin) cluster report. In Leukocyte Typing V: White Cell Differentiation Antigens. S.F Schlossman, L. Boumsell, W. Gilks, J. Harlan, T. Kishimoto, C. Morimoto, J. Ritz, S. Shaw, R. Silverstein, T. Springer, et al., editors. Oxford University Press, Oxford. 1756-1759.

45. Letarte, M., A. Bourdeau, S. Vera, N. Pece, A. Greaves, F. DignatGeorge, M.M.B. Kraling, K. Linask, E. O'Brien, M. Labinaz, et al. 1997. EC2 CD105 Workshop panel report. In Leukocyte Typing VI. Garland Publishing, Inc., London. In press.

46. Pichuantes, S., S. Vera, A. Bourdeau, N. Pece, S. Kumar, E.A. Wayner, and M. Letarte. 1997. Mapping epitopes to distinct regions of the extracellular domain of endoglin using bacterially expressed recombinant fragments. Tissue Antigens. 50:265-276.

47. Massagué, J. 1987. Identification of receptors for type- $\beta$ transforming growth factor. Methods Enzymol. 146:174-195.

48. López-Casillas, F., J.L. Wrana, and J. Massagué. 1993. Betaglycan prsents ligand to the TGF- $\beta$ signaling receptor. Cell. 73:1435-1444.

49. Cheifetz, S., H. Hernandez, M. Laiho, P. ten Dijke, K.K. Iwata, and J. Massagué. 1990. Distinct transforming growth factor- $\beta$ (TGF- $\beta$ ) receptor subsets as determinants of cellular responsiveness to three TGF- $\beta$ isoforms. J. Biol. Chem. 265:20533-20538.

50. Jennings, J.C., S. Mohan, T.A. Linkhart, R. Widstrom, and D.J. Baylink. 1988. Comparison of the biological effects of TGF beta-1 and TGF beta-2: differential activity in endothelial cells. J. Cell Physiol. 137:167-172.

51. McCarthy, S.A., and R. Bicknell. 1993. Inhibition of vascular endothe- 
lial cell growth by activin-A. J. Biol. Chem. 268:23066-23071.

52. Porteous, M.E.M., A. Curtis, O. Williams, D. Marchuk, S.S. Bhattacharya, and J. Burn. 1994. Genetic heterogeneity in hereditary haemorrhagic telangiectasia. J. Med. Genet. 31:925-926.

53. Shapiro, M.B., and P. Senapathy. 1987. RNA splice junctions of different classes of eukaryotes: sequence statistics and functional implications in gene expression. Nucleic Acids Res. 15:7155-7174.

54. Muller, G., J. Behrens, U. Nussbaumer, P. Bohlen, and W. Birchmeier. 1987. Inhibitory action of transforming growth factor $\beta$ on endothelial cells.
Proc. Natl. Acad. Sci. USA. 84:5600-5604.

55. Roberts, A.B., and M.B. Sporn. 1989. Regulation of endothelial cell growth, architecture and matrix synthesis by TGF- $\beta$. Am. Rev. Respir. Dis. 140: $1126-1128$

56. Dickson, M.C., J.S. Martin, F.M. Cousins, A.B. Kulkarni, S. Karlsson, and R.J. Akhurst. 1995. Defective haematopoiesis and vasculogenesis in transforming growth factor- $\beta 1$ knock out mice. Development. 121:1845-1854.

57. Shovlin, C.L. 1997. Molecular defects in rare bleeding disorders: hereditary haemorrhagic telangiectasia. Thromb. Haemostasis. 78:145-150. 